\title{
Priority areas for watershed service conservation in the Guapi-Macacu region of Rio de Janeiro, Atlantic Forest, Brazil
}

Vanesa Rodríguez Osuna ${ }^{1,2^{*}}$, Jan Börner ${ }^{1}$, Udo Nehren ${ }^{2}$, Rachel Bardy Prado ${ }^{3}$, Hartmut Gaese $^{1}$ and Jürgen Heinrich ${ }^{4}$

\begin{abstract}
Introduction: Land use intensification and urbanisation processes are degrading hydrological ecosystem services in the Guapi-Macacu watershed of Rio de Janeiro. A proposal to pay farmers to restore natural watershed services might be an alternative to securing the water supply in the long-term for the around 2.5 million urban water users in the study region. This study quantifies the costs of changing current land use patterns to enhance watershed services and compares these costs to the avoided costs associated with water treatment for public supply.

Methods: We use farm-household data to estimate the opportunity costs of abandoning current land uses for the recovery of natural vegetation; a process that is very likely to improve water quality in terms of turbidity due to reduced inputs from erosion. Opportunity cost estimates are extrapolated to the watershed scale based on remote sensing land use classifications and vulnerability analysis to identify priority zones for watershed management interventions. To assess the potential demand for watershed services, we analyse water quality and treatment cost data from the main local water treatment plant.
\end{abstract}

Results: Changing agricultural land uses for watershed services provision generally comes at high opportunity costs in our study area near to the metropolis of Rio de Janeiro. Alternative low cost watershed conservation options do exist in the livestock production sector. These options have the potential to directly reduce the amount of sediments and nutrients reaching the water bodies, and in turn decrease the costs of treatment needed for drinking water. Land cover changes at the scale needed to improve water quality will, nonetheless, likely exceed the cost of additional investments in water treatment.

Conclusions: The state water utility company's willingness to pay for watershed services alone will not be enough to induce provision of additional watershed services. We conclude that monetary incentives conditioned on specific adjustments to existing production systems could still have a complementary role to play in improving watershed services. However, we note that our willingness to pay analysis focusses on only one of the potentially wide range of ecosystem services provided by natural vegetation in the Guapi-Macacu watershed. Factoring these ecosystem services into the willingness to pay equation is likely to change our assessment in favour of additional conservation action, be it through PES or other policy instruments.

Keywords: Water services; Drinking water treatment; Water quality; Incentive-based watershed management

\footnotetext{
*Correspondence: vanesa@uni-bonn.de

${ }^{1}$ Center for Development Research (ZEF), Department of Economic and

Technological Change, University of Bonn, Walter-Flex-Str. 3, 53117 Bonn,

Germany

${ }^{2}$ Institute for Technology and Resources Management in the Tropics and

Subtropics (ITT), Cologne University of Applied Sciences, Betzdorfer Str. 2, 50679

Cologne, Germany

Full list of author information is available at the end of the article
} 


\section{Introduction}

One of the biggest challenges of our time is to revert the ongoing degradation of ecosystems while meeting the increasing demand for food and biomass (Thomas and Callan 2010; MEA 2005). Population and economic growth are increasing the demand for water resources and, at the same time, amplifying the pressure on ecosystems that deliver watershed services (Porras et al. 2008).

The degradation of ecosystem services represents a loss of widely undervalued natural capital assets (TEEB 2009; Montes 2007); MEA 2005. While there is general agreement that land use choices influence watershed service provision, the magnitude and nature of the effects are highly context dependent and poorly understood in tropical forest environments (Porras et al. 2008; Veiga 2008; Calder 2005; van Noordwijk 2005).

Land and water linkages are challenging to manage as watershed services have a common good characteristic (Porras et al. 2008) and are generally unaccounted for in monetary terms. As a result, they are often degraded and this is not reflected in traditional economic measures, such as GDP (TEEB 2009; Costanza et al. 1997; FAO 2007). Land use patterns and land management practices by upstream landholders in a watershed determine, to a great extent, quality and quantity of water bodies (Porras et al. 2008). For example, unsustainable land use and agricultural practices can result in negative hydrological side-effects, or externalities, such as sedimentation (Veiga 2008; MEA 2005). As a result, the design of policy measures that encourage farmers to adopt watershed conservation measures and, at the same time, maintain or even increase productivity has become a major research issue.

Several policy options are available to enhance incentives for the supply of ecosystem services. Commandand-control regulations, such as bans on forest clearing, have long been the preferred policy option to control environmentally harmful land use changes (Boerner and Vosti 2012; Porras et al. 2008; FAO 2007). More recently, mechanisms based on economic incentives or markets for ecosystem services are being proposed as cost-effective complementary tools to promote ecosystem service conservation (Porras et al. 2008; Engel et al. 2008; FAO 2007). These incentive-based mechanisms include payments for ecosystem services (PES) and payments for watershed services (PWS), water quality trading markets and reciprocal or in-kind agreements (Bennett et al. 2013).

Latin America registered a transaction value of USD 528.9 million in such investments between 2001 and 2011 corresponding to 3.4 million hectares (Bennett et al. 2013). PWS programmes are considered to be the "fastest growing" and most mature among all PES schemes in Latin America (Bennett et al. 2013; Balvanera et al. 2012;
Stanton et al. 2010). PWS in Latin America typically involve compensating upstream rural producers for protecting and/or restoring natural forest ecosystems and highland natural pastures (páramo) (Pria et al. 2013; Veiga and Galvadao 2011; Grieg-Gran et al. 2005). Such ecosystems are mostly located in strategic water production areas, such as headwaters, riparian forest or water intake points for water supply (Pria et al. 2013; Veiga and Galvadao 2011). There is, however, little evidence on the effectiveness of such schemes in meeting conservation and development goals in the peer-reviewed literature (see for example Arriagada et al. 2012; Pattanayak et al. 2010).

In Brazil, PWS are expanding and there are already 848 ecosystem service providers in the Atlantic Forest region alone, mainly organised or supported within the National Water Agency's Water Producer Programme (Veiga and Galvadao 2011; Santos et al. 2010). As of 2012, 41 PWS projects had been implemented or were in preparation, covering an area of around 40,000 hectares. A project in the state of Rio de Janeiro is currently in development, in the Três Picos State Park, Municipality of Cachoeiras de Macacu (Guedes and Seehusen 2011). This State Park is located in the mountainous area of the Guapi-Macacu watershed, which contributes to the supply of drinking water for almost 2.5 million inhabitants of five municipalities, including the city of Niteroi (Pedreira et al. 2009) and this watershed is the focus of the present study. The main drivers of degradation of water resources in this watershed are urbanisation processes, intensive agriculture and conversion of riparian vegetation.

Managing watershed services requires solid knowledge about (1) the costs of providing an additional unit of water quality or quantity (supply side) and (2) water users or intermediaries' willingness to pay for an additional unit of water quality or quantity (demand side). The economic aspects of watershed services supply and demand are particularly poorly studied and many PWS initiatives begin operating without quantitative knowledge of such parameters (Martin-Ortega et al. 2012). To address this knowledge gap, we focus on two research questions within our study area of the Guapi-Macacu watershed in the state of Rio de Janeiro:

1. What are the costs associated with shifting land uses to foster improved and enhanced watershed services (services supply)?

2. What are the treatment costs for the water supply company to improve water quality parameters such as turbidity?

Our focus is on understanding the supply and environmental conditions that determine watershed service provision. Particularly, we concentrate on the watershed service related to water quality maintenance in terms of 
turbidity reduction for supplying drinking water. However, we also analyse factors that influence water treatment costs (related to services demand) based on land use changes. The remainder of this paper is structured as follows, section "Assessing watershed services supply and demand" presents our approach, addresses relevant literature and concepts related to watershed service supply and demand, section "Methods" describes the study area and methods used for this research, section "Results" presents our findings, section "Discussion" discusses these findings and contextualises them with other studies and reviews the main caveats. Finally, section "Conclusions" presents our main conclusions and the policy implications for watershed service management.

\section{Assessing watershed services supply and demand The supply of watershed services}

Watershed service provision is to a large extent determined by land use and land cover. For example, unsustainable land use is frequently linked to a high surface runoff and an elevated concentration of suspended and soluble loads in water bodies (Batchelor et al. 1998). Changes in land cover, such as forest to agriculture conversion, tend to increase superficial runoff and sediment flux in rivers (FAO 2007; MEA 2005).

Healthy forest and wetland ecosystems are considered very effective at regulating water flow and improving water quality (Russi et al. 2013; TEEB 2010a,b). Maintaining water quality includes the control of sediment, nutrient (in particular phosphorous and nitrogen) and chemical loads, as well as salinity (TEEB 2010b). In addition, forest ecosystems can remove pathogenic microbes, sequester and convert inorganic ions and transform persistent organic pollutants (TEEB 2010b).

Watersheds with an important extension of forest tend to offer better water quality than those subject to other land uses, such as agriculture, pasture, industry and urban infrastructure, since the latter are associated with higher discharges of diverse types of pollutants into soils and water. In this way, the presence of forest could substantially reduce the cost of water treatment for drinking water in most cases, thereby reducing the related costs for water supply (Medeiros et al. 2011; Reis 2004).

Cities such as Rio de Janeiro, Johannesburg, Tokyo, Melbourne, New York and Jakarta all depend on protected areas with forests to provide drinking water for their residents (Dudley and Stolton 2003). Moreover, a third of the hundred largest cities worldwide take a significant proportion of their drinking water from protected forested areas (Dudley and Stolton 2003).

Worldwide several examples show that well-managed forests, wetlands and protected areas are very likely to supply clean water at significantly lower costs than man-made replacements, such as water treatment plants (Bennett et al.
2013; Hanson et al. 2011; TEEB 2009; Postel et al. 2005). Some examples are included in Table 1. For example, in the United States of America, 27 water suppliers showed that in watersheds with at least $60 \%$ forest cover, treatment costs were 50 percent less than those with $30 \%$ forest cover (Postel et al. 2005). Accordingly, several North American cities have decided to invest in watershed management to avoid the expense of water treatment plants.

In the literature regarding water quality, off-site effects of soil erosion are frequently referred to as sedimentation (Veiga 2008; Holmes 1988). A summary of economic activities most affected by loss of watershed services is presented in Table 2.

Different authors have classified ecosystem services in distinct ways (Haines-Young and Potschin 2013 Daily and Matson 2008; FAO 2007; Farber et al. 2006; MEA 2005; Postel et al. 2005; Hawkins 2003; De Groot et al. 2002; Costanza et al. 1997). In the current study, we followed the TEEB (2010b) classification of watershed services, whereby maintenance of water quality for human consumption is considered a provisioning service. We use this terminology throughout this article.

It is often argued that a major challenge of market mechanisms relates to the "packaging" of ecosystem services into commodities that are tradable or subject to a contract (Porras et al. 2008). However, most PWS schemes in developing countries are guided by a "landbased" approach, whereby suppliers are paid to improve their land management practices, which are in turn considered highly likely to result in watershed service provision, rather than being paid for the actual service delivery (Porras et al. 2008). Regardless of the approach chosen, watershed services supply is inevitably linked to farmers' land use decisions (FAO 2007). Consequently, watershed services supply analyses often require costbenefit analyses of agricultural production systems.

The concept of opportunity costs (OCs) is most frequently used to express the costs of additional watershed service provision. In the context of watershed services, OCs represent any benefits foregone by a farmer upon converting from their current land use to an alternative form of land use that is more watershed service-friendly.

Ideally, PWS are designed in such a way that payments compensate for at least the OCs of additional service provision or the foregone benefits of the land use promoted in order to provide the service. The extent to which such payments are or are not appropriate depends on the alternative land uses in each given area (Pagiola et al. 2010).

\section{The demand for watershed services}

When dealing with demand, we refer to those who are currently benefiting from the delivery of watershed services and to the resources available for protecting and conserving these services (Guedes and Seehusen 2011). 
Table 1 Examples of the economic values of watershed services

\begin{tabular}{|c|c|c|}
\hline Action & Examples & Source \\
\hline $\begin{array}{l}\text { Payments to maintain water purification services in the } \\
\text { Catskills watershed, New York avoid the costs of launching a } \\
\text { filtration plant for water treatment }\end{array}$ & $\begin{array}{l}\text { Payments for maintaining watershed purification represent } 1 \text { to } \\
1.5 \text { billion USD in comparison to the much higher estimated } \\
\text { cost of a filtration plant ( } 6-8 \text { billion USD plus 300-500 million } \\
\text { USD yearly for operating costs) }\end{array}$ & $\begin{array}{l}\text { Hanson et al. 2011; } \\
\text { WRI 2011; Pagiola } \\
\text { et al. } 2004\end{array}$ \\
\hline $\begin{array}{l}\text { The cost of removing nitrate contamination from water in } \\
\text { Rochester, Minnesota }\end{array}$ & 2.8-4.8 million USD per year & Hawkins 2003 \\
\hline $\begin{array}{l}\text { WTP for water quality improvement in the levels of iron, } \\
\text { sulphate, hardness, and copper in South-western, Minnesota }\end{array}$ & $\begin{array}{l}2.4,2.0,6.6 \text { and } 2.6 \text { million USD yearly respectively } \\
\text { (via contingent valuation method) }\end{array}$ & Hawkins 2003 \\
\hline $\begin{array}{l}\text { Yearly revenues in public utility resulting from natural water } \\
\text { supply in Mud Lake, Minnesota/ South Dakota }\end{array}$ & 94 USD per acre & Hawkins 2003 \\
\hline $\begin{array}{l}\text { Annual WTP from residents living close to the Minnesota } \\
\text { River for reducing phosphorous levels }\end{array}$ & $\begin{array}{l}\text { 14.1 USD via taxes or } 19.6 \text { USD via water bills for a } 40 \% \\
\text { reduction in a nearby river (contingent valuation method) }\end{array}$ & Hawkins 2003 \\
\hline $\begin{array}{l}\text { Increased reservoir water quality and surface area in St. } \\
\text { Louis, Missouri }\end{array}$ & Yearly net benefit of 25 million USD (travel cost method) & Hawkins 2003 \\
\hline Value of water supply in Milesburg, Pennsylvania & Between 14 and 36 USD per household (avoided cost) & Hawkins 2003 \\
\hline $\begin{array}{l}\text { In Venezuela, a national protected area system avoids } \\
\text { sedimentation }\end{array}$ & $\begin{array}{l}\text { Without the provision of this service by the national protected } \\
\text { area, unavoided sedimentation could reduce farmer's income } \\
\text { by approximately } 3.5 \text { million USD yearly }\end{array}$ & $\begin{array}{l}\text { Pabon-Zamora et al. } \\
2008\end{array}$ \\
\hline $\begin{array}{l}\text { The current provision of ecosystem services related to } \\
\text { existing stream vegetation along the Llobregat River, Spain }\end{array}$ & $\begin{array}{l}79,000 \text { EUR per year savings in water treatment costs for the } \\
\text { residents of Barcelona }\end{array}$ & $\begin{array}{l}\text { Honey-Roses et al. } \\
2013\end{array}$ \\
\hline $\begin{array}{l}\text { In New Zealand, the value of water provision from the } \\
\text { Otago region coming from the Te Papanui Conservation Park }\end{array}$ & $\begin{array}{l}\text { Now it is "free" but would cost } 136 \text { million NZDa to bring it in } \\
\text { from somewhere else (total benefit of the service) }\end{array}$ & TEEB 2009 \\
\hline
\end{tabular}

${ }^{a} 1$ USD is equivalent to 1.30 NZD at current exchange rate (http://www.oanda.com/currency/converter/).

Table 2 Examples of economic activities most affected by the loss of watershed services

$\begin{array}{ll}\text { Economic activities and } & \text { Examples of incurred costs/damages due to the loss of watershed services Source } \\ \text { damage caused by the loss } & \\ \text { of watershed services }\end{array}$
of watershed services

Activities that depend on reservoirs

Capacity loss for energy generation

Veiga 2008; Reis 2004

Capacity loss of irrigated production

Loss of benefits related to flood control

Capacity loss of navigation channels

Increase of suspended material/siltation of water bodies resulting in a reduction of their storage capacity

Drainage and maintenance operations

Increased water treatment costs related to augmented turbidity

Monetary damages related to sedimentation
Costs related to (a) irrigation and drainage of channels, (b) hydroelectric plant reservoirs, (c) ports and (d) eutrophication (increase concentration of $\mathrm{N}$ and $\mathrm{P}$ in water bodies)

One example are watersheds in São Paulo with lower costs related to consumption of chemical products for the water treating process (less than $20 \mathrm{BRL}^{\mathrm{a}}$ per $1,000 \mathrm{~m}^{3}$ of treated water) were those with a forest cover higher than $15 \%$. The two water treatment units with less percentage of forest cover (Piracicaba and Atibaia rivers with less than $10 \%$ forest cover) show considerably higher specific costs of chemical products

Additional annual costs from 35 to 661 million USD for a US water treatment plant due to soil erosion. These values relate strongly to agricultural production causing sedimentation

Additional annual operational cost of 3.2 BRL per hectare and 0.10 BRL per ton of eroded soil for the water treatment of the river Corumbataí in São Paulo. These estimates were made assuming that the only externality caused by soil erosion were increased water treatment costs but not taking into account siltation of river banks, flooding of areas close to river banks and loss of navigation capacity
Veiga 2008; Reis 2004

Reis 2004; Dearmont et al. 1998; Holmes 1988, Moore and McCarl 1987

López 1997; Holmes 1988 
Besides PWS, which are carried out by national states in Latin America, a user's fee system can be an effective approach to efficiently use water resources. The watersheds of the rivers Piracicaba, Capivari and Jundiaí (PCJ) in the state of São Paulo have implemented such a user's fee system with around 8.8 million of beneficiaries of the Cantareira system (Veiga and Galvadao 2011). In this situation, an Inter-Municipal Basin Committee was formed to manage a watershed protection fund and contributions to the fund come from the municipal water utility budgets.

As a further alternative, some programmes in the Atlantic Forest region are subsidised by the government, for example: "Bolsa Verde", "ProdutorES de Água" and "Mina D'água" in the states of Minas Gerais, Espírito Santo and São Paulo, which pay rural producers for conservation activities on their properties (Guedes and Seehusen 2011). These include the protection or restoration of native vegetation areas with a focus on headwaters and riparian forests (Guedes and Seehusen 2011; Veiga and Galvadao 2011).

Another significant source of finance for PWS in developing countries comes from the international public sector funding or development assistance (Porras et al. 2008). A key provider to this funding is the Global Environmental Facility (GEF), which acts as buyer on behalf of service users for conserving global public services. Around 108 million USD and 52 million USD have been made available as World Bank (WB) loans and GEF grants respectively for WB/GEF-supported PWS projects (FAO 2007). For example, the World Bank has given loans to support the development and implementation of well-known PES programmes in Mexico and Costa Rica (FAO 2007). Involvement of the private sector in paying for ecosystem services, including in the context of corporate social responsibility, is growing (TEEB 2010c).

Considering these factors, supply and demand analysis of watershed services provides essential information to assess the economic and financial viability of PWS schemes (IIED 2012a). Figure 1 illustrates our approach in identifying the economic preconditions for a potential PWS scheme in the Guapi-Macacu watershed.

As the figure suggests, we expect PWS to be a viable policy option only if the willingness of water users to pay (i.e. the demand of the water company) exceeds the opportunity costs (OCs) of additional watershed service provision (supply) incurred by land users in the watershed.

\section{Methods}

\section{The Guapi-Macacu watershed}

The study area lies within the Guapi-Macacu watershed $\left(1,263 \mathrm{~km}^{2}\right)$, which is located in the Serra do Mar biogeographical region (Ribeiro et al. 2009) and is a priority conservation target within the Atlantic Forest biodiversity hotspot in the state of Rio de Janeiro (CEPF 2001), see Figure 2.

The Atlantic Forest biome is characterised by historically high deforestation rates (Dean 1997), resulting in a highly fragmented area with numerous isolated and disperse forest fragments in a landscape dominated by agricultural

\section{WATERSHED SERVICE (WS): WATER QUALITY MAINTENANCE FOR DRINKING WATER PUBLIC SUPPLY}

\section{WATERSHED SERVICE SUPPLY}

Farming Systems

-Farm structure: relation to rural property, dependency on agricultural production, condition of land tenure, labour availability, property characteristics, land use shares

-Production patterns: main crops, fertilizer \& agrochemical use, soil preparation \& management practices, animal production

-Forest related variables: perceived land use \& water quality changes

\section{Key environmental conditions influencing} watershed service's supply

-State: i.e. slope, index of riparian forest fragments \& springs

-Pressure: i.e. land use

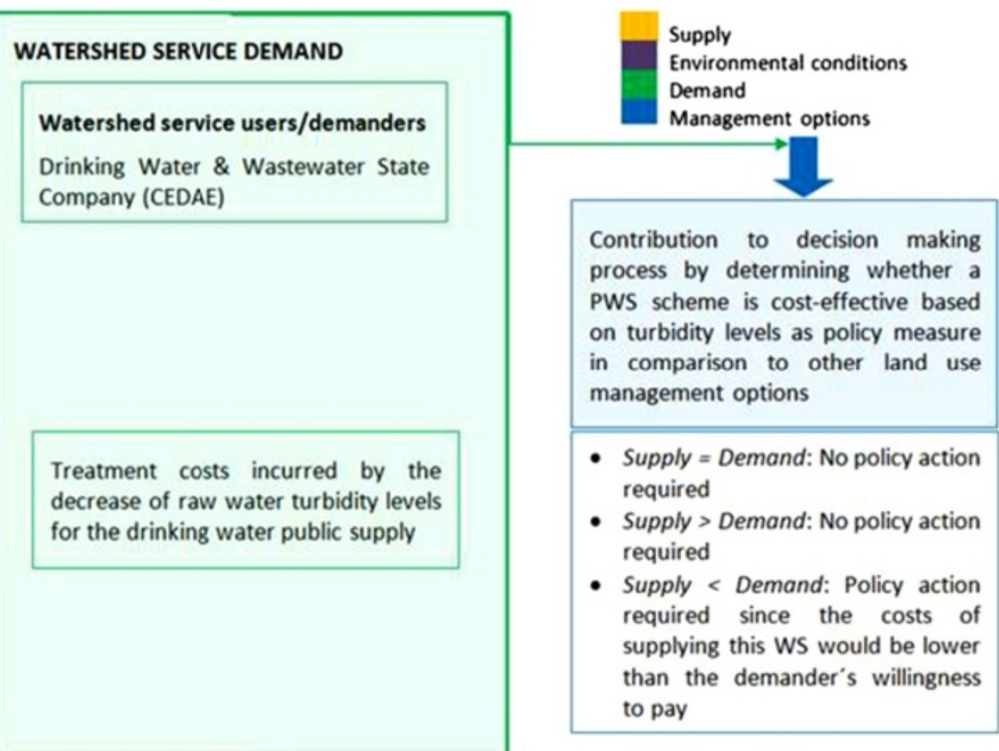

Figure 1 Conceptual framework for assessing watershed services. This framework considers water quality maintenance for public supply considering supply is at the farming system level and demand is at the watershed level. 


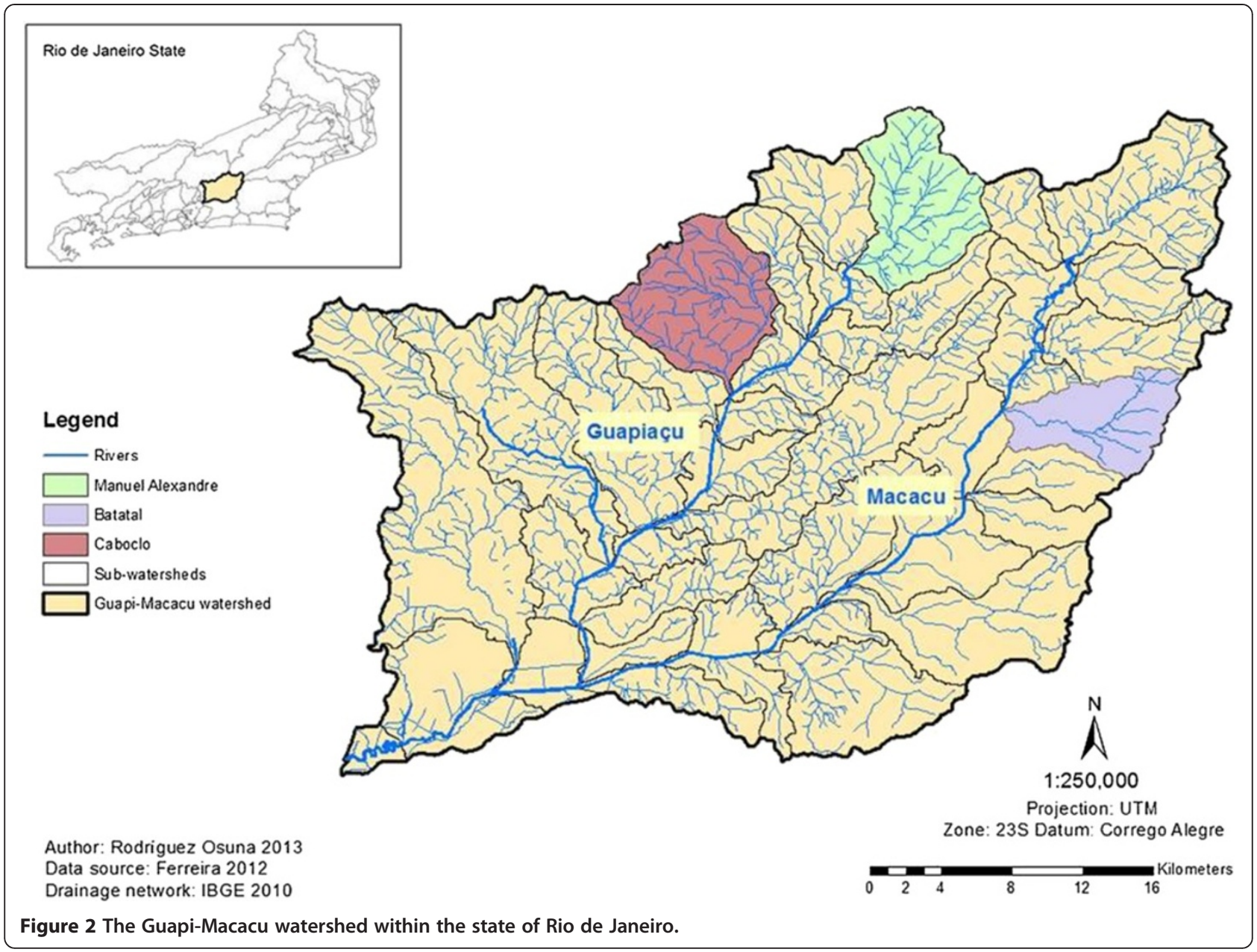

production systems (Nehren et al. 2013; Ribeiro et al. 2009). This biome supplies 135 million people with water (Pria et al. 2013); however, a mere 11 to 16 percent of its original forest cover is left (Ribeiro et al. 2009).

Forest cover in the state of Rio de Janeiro and more specifically in the Guapi-Macacu watershed, is comparatively high due to its rugged topography. Unfortunately, continuous forest cover occurs mostly on steep slopes that are inappropriate for agriculture, while the foothills and lowlands are dominated by agriculture and pasture (Nehren et al. 2013; Strobel et al. 2007). In 2008, the land cover/land use of the Guapi-Macacu watershed consisted of forests in all stages (48.8\%), pastures (41.4\%) and agriculture (4.4\%). The remaining 5.4\% were covered by urban areas, water bodies, bare soil, rock outcrop, wetlands and mangrove (Fidalgo et al. 2008).

Rivers and creeks in the Guapi-Macacu watershed originate mainly in the State Park "Três Picos", but some stem from the National Park "Serra dos Órgãos" and in the State Ecological Station "Paraíso". The main rivers Macacu and Guapiaçu originate within the State Park and constitute the main components of this watershed (Strobel et al. 2007).
The water intake point of the water supply is located in the lower part of the watershed and managed by the Drinking Water and Wastewater State Company (CEDAE). Due to the good water quality coming from the springs of the rivers Macacu and Guapiaçu, several mineral water companies have been established in the region, as well as enterprises for which water is an essential input (Strobel et al. 2007)

In the Guapi-Macacu watershed, various demands in water supply to domestic, industrial and agricultural consumption are taking place as a result of the good water quality from the water sources of the main rivers (Strobel et al. 2007). Moreover, the ongoing construction of a new petrochemical complex (COMPERJ) in the downstream area of the watershed is expected to further increase both water demand and pressure on natural resources in the study area (Pedreira et al. 2009).

Within the watershed, three sub-watersheds (see Figure 3): (I) Manuel Alexandre, (II) Batatal and (III) Caboclo were selected for this study. Each of these sub-watersheds represents the different types of land cover mix found in the area, namely "forest", "agriculture" and "pasture", which 

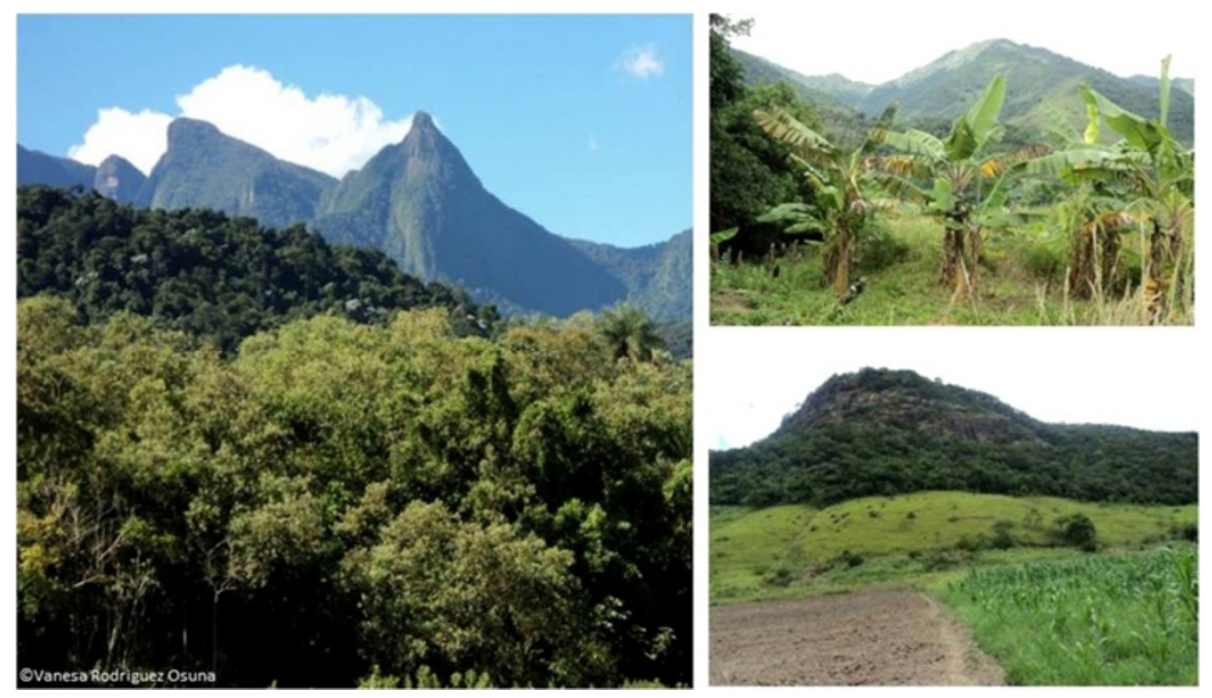

Figure 3 Sub-watershed landscapes of three rivers: Manuel Alexandre (left), Batatal (upper right) and Caboclo (lower right).

account altogether for around $95 \%$ of the total watershed area. By selecting three sub-watersheds with greatly varying land use patterns and intensities, we were able to compare them with respect to their differences on agricultural profitability and their distinctive impact on water quality parameters: in this case turbidity levels.

(I) The sub-watershed Manuel Alexandre is located in the Ecological Reserve of Guapiaçu (REGUA) and represents a well-preserved landscape with a high proportion of forest land (87\%) (Fidalgo et al. 2008). It therefore served as the reference for a nature-near, less disturbed forest ecosystem. This area includes a private reserve with low human impact resulting primarily from ecotourism in the form of birdwatchers. Most of the area within this sub-watershed is protected under the REGUA Association, which is financially supported by the Brazilian Atlantic Forest Trust (BART) with the stated objective of protecting the Atlantic Rainforest of the upper Guapiaçu river watershed. This is mainly done by enlarging protected areas through land purchase.

(II) In contrast, the sub-watershed Batatal represents a mixed system of the most relevant land uses with a mosaic of forest fragments (69\%), pastures (28\%) and agriculture (4\%) considering the land use classification by Fidalgo et al. (2008). Predominantly, banana (perennial) is found in higher elevation areas, followed by annual crops mainly found in flat areas or lowlands (cassava, maize, beans and vegetables). Forest fragments in different stages of ecological succession are found in high elevation areas.
(III) In the Caboclo sub-watershed, the predominant land use type is forest (81\%), followed by pasture (14\%) and agriculture (3\%) according to Naegeli (2010) and Fidalgo et al. (2008). Agricultural systems with a considerably higher intensity than in Batatal are found in this sub-watershed, mainly along the floodplain. The most common annual crops are maize, cassava, beans and vegetables, whereas perennial crops are rare. The higher elevation area is within the boundaries of the State Park Três Picos, where agricultural activities are carried out within the buffer area of this Park.

Both sub-watersheds, Batatal and Caboclo have undergone historical exploitation cycles, resulting in high deforestation, forest fragmentation and degradation, as well as intense soil erosion (Nehren et al. 2013).

\section{Methods to assess supply of watershed services}

To calculate the opportunity costs (OCs) related to the provision of watershed services under varying land use systems, we carried out a cost-benefit analysis of representative farming systems in the region. For this, we developed detailed individual budgets for all activities within a given farming system (for definition see Beets 1990). Activity budgets summarised revenue and cost information and were finally aggregated to calculate the average rate of return for each land use type (WBI 2011). Crop budgets were compared for coherence with official current production costs used by the Rural Extension and Technical Assistance Agency (EMATER) of the state of Rio de Janeiro.

Our target population was households practicing some degree of agriculture at the sub-watershed level considering 
the sub-watersheds of Batatal and Caboclo. A household survey was carried out in two field campaigns in 2011 and 2012 with the permanent support of key local producers, EMATER of the municipality of Cachoeiras de Macacu, the City Council of this municipality and Embrapa Soils scientists. Expert interviews were carried out with the Director of the REGUA Reserve and other staff members in Manuel Alexandre sub-watershed, to better understand land use history and recent management practices in the region.

To define the sample universe, we created an inventory using the indirect census technique following Forero (2002). This process consisted of a participatory mapping exercise based on recent aerial imagery provided by the City Council of Cachoeiras de Macacu. This enabled us to assemble a list of all farm units within the sub-watersheds, which was confirmed by extensive field visits and supported thoroughly by local experts including a member of the Agricultural Department of the City Council (Cachoeiras de Macacu), the President of the Faraó Farmer's Association (A.L.A.F.) in the sub-watershed of Batatal, a member of the Rural Workers Union (in the sub-watershed of Caboclo) and the Director of the REGUA Reserve (Manuel Alexandre sub-watershed). As a result, a total of 32 households in Batatal and 60 in Caboclo were identified, of which 78 households within the two populated sub-watersheds were interviewed using a semi-structured survey. No interviews were made in the reference site of Manuel Alexandre sub-watershed. The sample size obtained is supported by Angelsen et al. (2011), who suggest a minimum sample size of 25-30 households from each community. This is valid for communities with 100 to 500 families. The designed questionnaire was based on various scientific publications and reports (see Rodriguez Osuna 2013; Angelsen et al. 2011; WBI 2011; Gaese 2009; Instituto Terra Mater 2009; Forero 2002).

Throughout the course of our fieldwork, two survey rounds were carried out. The first survey round included a random sampling of farm units within each sub-watershed to define "representative farming systems". Important selection criteria for these farming systems as suggested by Zimmer et al. (2009) and local experts included mainly: farm size, land tenure, production programme and agricultural management practices, and average location of farms in terms of metres above sea level (m.a.s.l.).

Once such farming systems were defined, a second survey round was launched to explore in-depth characteristics of farming systems with special attention to the inputs and outputs that are relevant to profitability among such systems.

In the sub-watershed of Batatal, we divided the farming systems by location in upland versus lowland, since this division significantly affects production patterns. Farm units in the uplands are located at an average altitude of 344 m.a.s.l. in contrast to those in the lowlands located at ca. 83 m.a.s.l. Agricultural production in the lowlands of Batatal is comparable to those sub-watersheds located along the Macacu River. The same occurs in Caboclo, which is representative for sub-watersheds along the Guapiaçu River (Figure 2).

Subsequently, a cost-benefit analysis was carried out for each farming system. The occurrence of each farming system was estimated and validated through local expert consultation as suggested by Angelsen et al. (2011).

Our sampling strategy focused on capturing the diversity of smallholder production systems in the region, yet our total sample size was too small to obtain a representative sub-sample of the large cattle operations that dominate in the lower part of the watershed. For the cost-benefit analysis of cattle production systems, we thus relied on additional in-depth interviews with a group of livestock producers deemed representative by officers of EMATER.

Based on interviews with selected livestock producers and secondary data on livestock systems in this area (see Quintana 2012), we calculated livestock activity budgets for three slope categories: 1) $\leq 15^{\circ}$; 2) $16-25^{\circ}$ and 3) $>25^{\circ}$. These budgets were calculated under the assumption that profits for livestock production decreased with increasing slope, because of lower productivity of pasture, among other factors. This assumption is based on interviews with local farmers.

Once profits for agricultural and livestock systems were obtained, they were extrapolated to the watershed level using a Landsat based land cover classification that identified "agriculture" and "pasture" areas (Pedreira et al. 2009; Fidalgo et al. 2008). The agricultural profit calculated in the selected sub-watersheds (only considering lowland areas) was applied to all sub-watersheds in the same river network. In the sub-watershed of Batatal, we divided farming systems located in uplands and lowlands since this division influences significantly production patterns. This was not necessary in the Caboclo sub-watershed, where all farming systems are located in the lowlands.

The profit derived from farming systems is equal to the opportunity cost of converting agricultural or pastoral lands to forest, thereby reducing turbidity. For example low OCs are associated with low profits from current land use. Per hectare OC estimates for each subwatershed thus represent the weighted average per hectare profits from the respective land cover types.

We relied on a spatial analysis of the vulnerability of water resources in the study area (Ferreira 2012), which was understood as the likelihood of watershed service loss. In this case, our assessment considered state and pressure indicators following the Driving Forces, Pressure, State, Impact and Response (DPSIR) framework (see Borja et al. 2006), where $50 \%$ were state indicators including: geomorphology, hydrogeology, drainage density, soils, index 
of circularity, index of areas of permanent protection (APP) fragments and slope. APP areas are established by the Brazilian Forest Code (Federal Law 4771/1965) and are defined as "protected areas, both covered or not with native vegetation, that have the environmental functions of preserving water resources, landscapes, geological stability, biodiversity, and genetic fluxes of flora and fauna, as well as protection of the soil and securing the wellbeing of human populations" (Ministry of Environment 2005). These areas include a minimum vegetation area to protect riverbanks and headwaters. The other $50 \%$ included pressure or anthropogenic indicators such as phosphorous $(\mathrm{P})$ and nitrogen $(\mathrm{N})$ production, land use and road density (Ferreira 2012). All mentioned factors (state and pressure) were weighed by hydrological expert consultation by Ferreira 2012 (Figure 4). Single indicators were based mostly on published official maps predominantly generated by Embrapa Soils.

Our next step was to identify priority areas for watershed service provision. For this, we overlaid environmental and economic criteria, i.e. vulnerability of water resources and spatial OCs within the Guapi-Macacu watershed. This allowed us to identify the areas where low OCs of shifting land use towards improving watershed services can result in high watershed service payoffs. These sub-watersheds were given the highest priority for intervention with watershed service improvements. Second and third priorities were given to subwatersheds with high OCs and vulnerability and those with low OCs and vulnerability, respectively. The latter is based on the assumption that environmental goals are more important than cost criteria. However, this could be changed when there are budget restrictions and when there is intent to increase efficiency of payments in compensation schemes for watershed services. The lowest priority areas are those sub-watersheds with high OCs and low vulnerability of water resources.

\section{Methods to assess the potential demand for watershed services}

Demand for watershed services was assessed by identifying costs related to the end-user of those services (HoneyRoses et al. 2013). For this particular study case, it included quantifying water treatment costs incurred by the main watershed user, the state water utility (CEDAE). Water treatment costs that may be avoided if forests are restored can be translated as the potential willingness to pay (WTP) for watershed services. For example, if a one unit reduction in turbidity levels implies 10 additional monetary units in treatment costs, the water company's maximum WTP for watershed services will be 10 .

We applied the avoided cost method focusing on the annual operational costs of chemical products for the treatment of raw water in the period between 1998 and 2011 from the local state water utility company. This approach required identifying key water quality indicators related to the main operational cost categories of the water utility company.

Based on expert interviews and as suggested by Medeiros et al. (2011), Reis (2004) and Dearmont et al. (1998), we

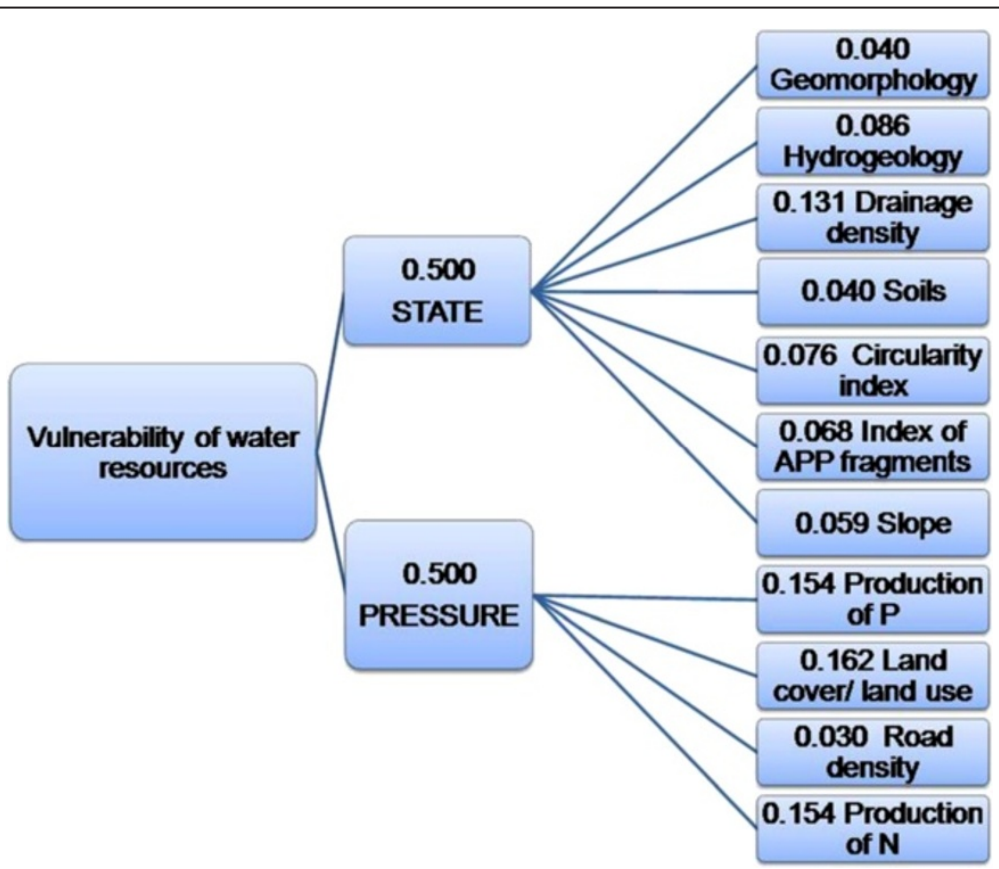

Figure 4 State and Pressure Indicators to assess water resources vulnerability. These indicators were weighed by hydrological expert consultation to assess the vulnerability of water resources in the Guapi-Macacu watershed (Modified from Ferreira 2012). 
identified turbidity as the key indicator amongst all water quality parameters, since an increase in turbidity implies an increased concentration of suspended solids in surface waters and is likely to reduce the quality of raw water to be treated by the water utility. The conversion of forest to other land uses such as agriculture or pasture caused by farming systems can result in higher turbidity values, which in turn correlate with higher water treatment costs to reduce the concentration of suspended solids for public water supply (Medeiros et al. 2011; Reis 2004; Dearmont et al. 1998).

In addition Medeiros et al. (2011) and Reis (2004) suggest that chemical products account for close to $60 \%$ of annual operational costs in treatment plants in São Paulo (Reis 2004). These products are used to flocculate the suspended particles, measured as turbidity, that are found in raw water to fulfill regulations on drinking water quality for human consumption (maximum value of $5 \mathrm{NTU}$ ).

\section{Results}

\section{Vulnerability of water resources}

Water resource vulnerability is a function of both anthropogenic impact/pressure indicators and of environmental state indicators, so the assessment of vulnerability must account for this set of indicators. When only considering environmental state indicators, sub-watersheds located in higher areas of the Guapi-Macacu watershed tend to have higher vulnerability to anthropogenic pressure than those in the lowlands (Ferreira 2012). Pressure indicators in a watershed are highly influenced by population density, land use practices, presence of urban settlements, road density and other factors previously mentioned. Therefore, the sub-watersheds with relatively high anthropogenic impacts are those with a high density of urban settlements and rural population nuclei. Subwatersheds found in higher areas of the watershed have considerably lower impact values (Ferreira 2012).

Figure 5 shows the sub-watersheds with higher vulnerability in the darker tones and those with lower vulnerability in the lighter tones. The less vulnerable subwatersheds are found in the lower areas of the watershed and one of these is considered a natural protected area with limitations and restrictions in land use, despite its lower vulnerability.

\section{Agricultural production and opportunity costs}

Field surveys carried out in the Batatal and Caboclo subwatersheds showed differences in production patterns and differences in specific environmental factors that reflect both the effect of farming systems on the provision of watershed services as well as distinct farming systems' profitability.

Relevant characteristics that differ considerably across these two sub-watersheds include land tenure and land use. In Batatal, most of the land is obtained by heritage or with a provisionary land title (66\%), followed by banana share-croppers (19\%), who are generally entitled to half the harvest. In contrast, in Caboclo most of the population lives within a settlement that keeps a common forest area called a "private reserve". This reserve is protected and is restricted from cultivation. Therefore, $85 \%$ of the farm-households in Caboclo are located in the lowlands, while the rest are found on the hillsides. In both sub-watersheds, one farm unit does not surpass 14 hectares, which is considered typical for family-oriented agriculture for the municipality of Cachoeiras de Macacu (MDA 2010). After considering the specific differences among farming systems in Batatal and Caboclo, four types of farming systems (FS) were classified in Batatal and two in the sub-watershed of Caboclo (Table 3).

In Batatal, we found that $80 \%$ of FS in the uplands are specialised in banana (Musa sp.) production (classified as FS 1 ) and $20 \%$ had a mixed system of cassava (Manihot sp.) and banana (FS2). In the lowlands of Batatal, two additional FS where agriculture is more intensive were classified as FS3 and FS4 and are equally distributed. FS3 has a production system composed of cassava, green maize (Zea mays), yams (Colocasia sp.) and courgette (Cucurbita sp.), while FS4 has the same mix of cassava, green maize and yams, but banana instead of courgette (Table 3).

Cassava is the dominant crop in the Caboclo subwatershed, followed by green maize, yams and common beans (Phaseolus vulgaris). Cassava is the most cultivated crop, mainly due to low investment requirements and because of relatively stable returns after a cropping period of 8 to 9 months. Green maize requires higher investments; however, it provides relatively rapid returns after only 90 days. Common beans are used to improve soil fertility (nitrogen fixation) and as an alternative to the other products. Other relevant short-cycle products are okra (Hibiscus esculentus) and gilo (Solanum gilo).

The most common farming system in the Caboclo sub-watershed (FS5) combines cassava, yams, common beans and green maize (70\%), while the rest (FS6-FS6a) combine cassava, yams, common beans, green maize and -additionally- okra or gilo (Table 3). Typically, green maize, courgette and beans are planted twice in one cropping cycle.

Agriculture in the uplands of Batatal is clearly less intensive in fertilizer use than in the lowlands, especially given that banana production in the uplands is carried out without fertilization. The remoteness of these locations makes intensive production less attractive than in the lowlands. In the lowlands of Batatal, vegetable producers applied on average of $240 \mathrm{~kg}$ of fertilizer per hectare each year. In Caboclo, more than $70 \%$ of households used fertilizers for their agricultural production, at an average of $547 \mathrm{~kg}$ per hectare each year. 


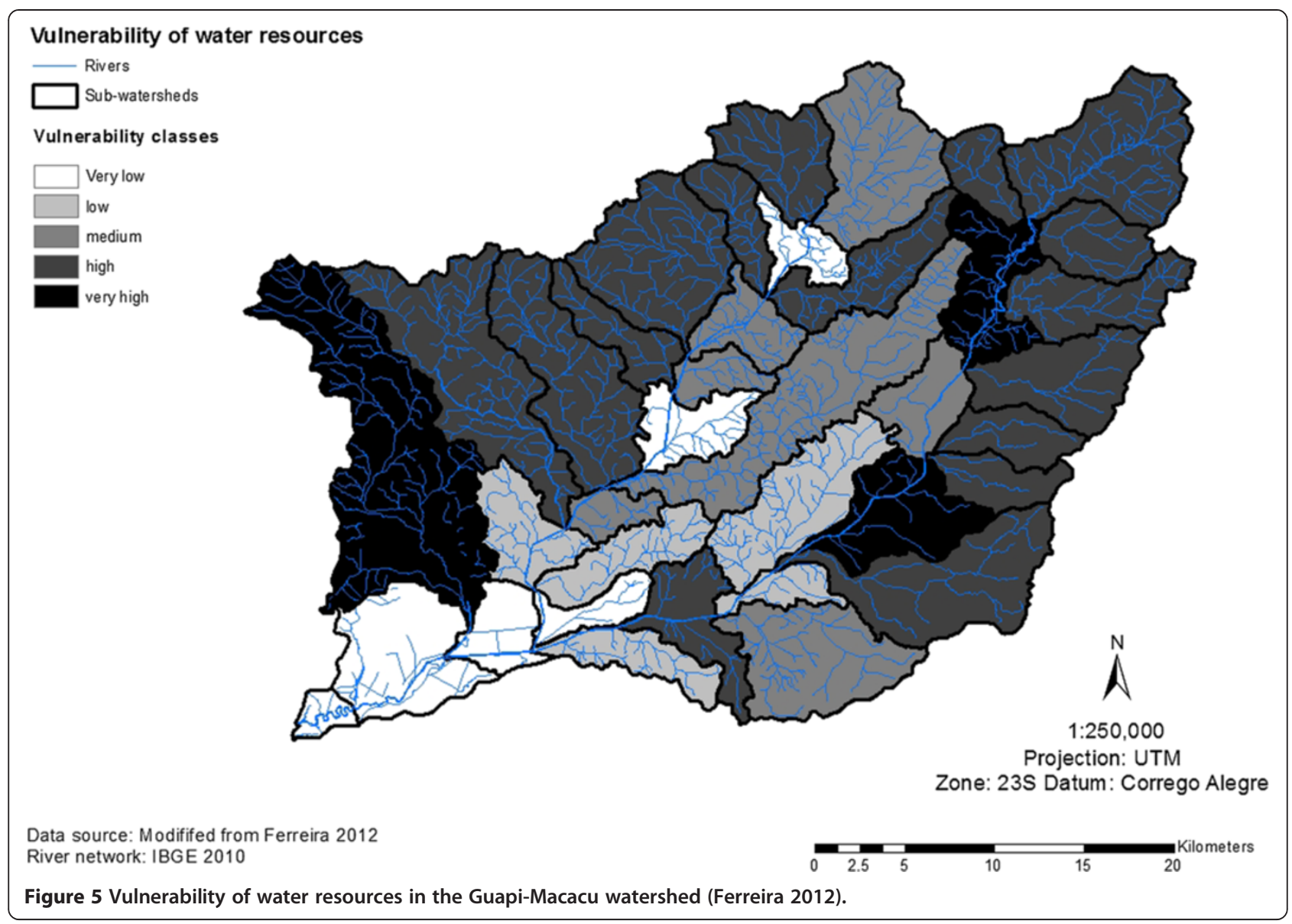

In the uplands of Batatal, all households used herbicides as their basic approach to weed control, whereas a variety of agrochemicals were used in the lowlands. The high use of herbicides for weed control could be the result of the shortage of and high cost of labour that would otherwise undertake this activity. It should also be noted that the Atlantic Forest Law (Law 11.428/1986) and the Brazilian Forest Code (Law 12.651/2012) bring certain limitations to agricultural production. The Atlantic Forest Law bans the conversion of secondary forest into land uses such as agricultural land. As an example, a collapse of the market price for banana around fifteen years ago left many banana plantations uncultivated and secondary forests developed and expanded, leading to abandonment of these plantations. In addition, the Brazilian Forest Code defines for the Atlantic Forest Biome that $20 \%$ of rural properties need to be maintained as a permanent forest reserve "Reserva Legal". The Brazilian Forest Code also prohibits the clearing of primary vegetation on steep slopes $\left(>45^{\circ}\right)$, along the margins of rivers and streams and in headwater (source) areas, which are classified as areas of permanent protection (APPs) (Ministry of Environment 2005).
In Batatal, the per hectare average annual profit was estimated at 4,115 BRL and in Caboclo at 5,052 BRL (Table 3). Returns for agriculture tend to be higher in the lowlands, where the intensity of production is higher than in the uplands, and there is a higher use of agricultural inputs especially fertilizers for cash crops.

According to local expert interviews small livestock farmers are considered those with farm size less than 20 hectares, while big-scale producers are considered those with more than 400 hectares. According to official cattle vaccination data in the Municipality of Cachoeiras de Macacu in 2011, an estimation of the herd size can be given on the base of vaccinated animals. This resulted in 27,995 animals in all three districts of this Municipality (Secretary of Agriculture, Cattle Farming, Fisheries and Supply 2011). Most livestock farmers (90\%) have less than 500 animals and small-scale producers are considered in this municipality those with less than 20 animals. Mostly, animals are distributed in paddocks without dividing fences.

Livestock production systems achieved profits of 20, 40 and $100 \mathrm{BRL}$ per hectare annually, depending on slope class (Table 3 ). 
Table 3 Summary of annual farming systems profits in the study area

\begin{tabular}{|c|c|c|c|c|c|c|c|c|c|c|c|}
\hline \multirow[t]{3}{*}{ Main crops } & \multirow[t]{3}{*}{ Unit } & \multicolumn{4}{|c|}{ Batatal sub-watershed } & \multirow{2}{*}{\multicolumn{3}{|c|}{$\begin{array}{l}\text { Caboclo sub-watershed } \\
\text { Lowland }\end{array}$}} & \multirow{2}{*}{\multicolumn{3}{|c|}{$\begin{array}{l}\text { Pasture land systems } \\
\text { oriented to beef production } \\
\text { considering slope }\end{array}$}} \\
\hline & & \multicolumn{2}{|c|}{ Upland } & \multicolumn{2}{|l|}{ Lowland } & & & & & & \\
\hline & & FS1 & FS2 & FS3 & FS4 & FS5 & FS6a & FS6b & $\leq 15^{\circ}$ & $\begin{array}{l}16^{\circ} \text { to } \\
25^{\circ}\end{array}$ & $>25^{\circ}$ \\
\hline Banana & & 972 & 972 & 983 & & & & & & & \\
\hline Cassava & & & $-1,334$ & 3,950 & 3,950 & 5,231 & 5,232 & 5,232 & & & \\
\hline $\begin{array}{l}\text { Green maize } \\
\text { (summer) }\end{array}$ & & & & 2,371 & 2,371 & 2,066 & 2,067 & 2,067 & & & \\
\hline Green maize (winter) & & & & 3,438 & 3,438 & 2,371 & 2,371 & 2,371 & & & \\
\hline Yam & (BRL) & & & 2,861 & 2,861 & 6,199 & 6,199 & 6,199 & & & \\
\hline Courgette & & & & & 3,633 & & & & & & \\
\hline Gilo & & & & & & & & 10,941 & & & \\
\hline Okra & & & & & & & 10,092 & & & & \\
\hline Beans (summer) & & & & & & 1,419 & 1,419 & 1,419 & & & \\
\hline Beans (winter) & & & & & & 1,522 & 1,523 & 1,523 & & & \\
\hline Occurrence & (\%) & 80 & 20 & 50 & 50 & 70 & 15 & 15 & & & \\
\hline $\begin{array}{l}\text { Typical area and crop } \\
\text { distribution for each } \\
\text { farming system (FS) }\end{array}$ & (ha) & 10.3 & $\begin{array}{l}10.3 \text { ( } 8.3 \text { banana, } \\
2.0 \text { cassava) }\end{array}$ & $\begin{array}{l}6.0 \text { ( } 2.0 \text { cassava, } 2.0 \text { green } \\
\text { maize, } 1.0 \text { yam, } 1.0 \text { banana) }\end{array}$ & $\begin{array}{l}6.0 \text { ( } 2.0 \text { cassava, } 2.0 \text { green } \\
\text { maize, } 1.0 \text { yam, } 1.0 \text { courgette) }\end{array}$ & $\begin{array}{l}4.0 \text { ( } 1.0 \text { cassava, } \\
1.5 \text { green maize, } \\
1.0 \text { yam, } 0.5 \text { beans) }\end{array}$ & $\begin{array}{l}4.0(1.0 \\
\text { green } \mathrm{n} \\
0.5 \mathrm{okra}\end{array}$ & $\begin{array}{l}\text { va, } 1.5 \\
0.5 \text { yam, } \\
\text { ilo, } 0.5 \text { beans) }\end{array}$ & & & \\
\hline Per hectare profit & $\left(\mathrm{BRL} \mathrm{ha}^{-1}\right)$ & 972 & 526 & 3,894 & 4,336 & $4,889.7$ & $5,376.3$ & $5,482.5$ & 20 & 40 & 100 \\
\hline Average value for & (ס) & Maca & cu River lowland & & & Guapiaçú River & & & & & \\
\hline $\begin{array}{l}\text { extrapolation at } \\
\text { the watershed level }\end{array}$ & (BRL na ) & 4,114 & & & & $5,051.6$ & & & 20 & 40 & 100 \\
\hline
\end{tabular}

${ }^{\mathrm{a}}$ According to expert interviews, there is a gain of 40 to $60 \mathrm{~kg}$ of live animal weight in high slope areas in contrast to those in lowlands with a gain in live animal weight of 120 to $150 \mathrm{~kg}$ in this particular watershed; a According to expert interviews, there is a gain of 40 to $60 \mathrm{~kg}$ of live animal weight in high slope areas in contrast to those in lowlands with a gain in live animal weight of 120 to $150 \mathrm{~kg}$ in this particular watershed;
bSince upland agriculture in the Batatal sub-watershed (FS1 and FS2) was not detected by the available land use classification (Naegeli 2010; Pedreira et al. 2009; Fidalgo et al. 2008), we were limited to using average per hectare annual profits for lowland agriculture in Batatal (FS3 and FS4) resulting in an average annual per hectare value of 4,114.8 BRL. 
Area-weighted OCs per sub-watershed were spatially mapped, ranging from 14 to $1,660 \mathrm{BRL}$ per hectare (Figure 6). This reflects that extensive pasture is the most important land use in the Guapi-Macacu watershed according to area, which is an activity with comparatively low per hectare profits.

Figure 5 shows that quite a number of high $\mathrm{OC}$ areas are located close to the main two river beds, where intensive agriculture predominates. Resulting OCs from agriculture occur only in lowlands and close to the river plain, which have higher nutrient concentration than in higher slope areas.

Low OCs areas are often either located in the steep slope areas of the upper watershed or in the valleys, where extensive pasture areas dominate. However, these areas are also found in the lower parts of the watershed, where a small-scale settlement promoting family-oriented cattle ranching was launched a decade ago by the government of Rio de Janeiro.

Forests predominate mainly in higher slope areas (mostly in white in Figure 6), which originate, to a great extent, in protected areas such as the State Park "Três Picos", the National Park "Serra dos Órgãos" and the State Ecological Station "Paraíso".

\section{Analysis of environmental and economic criteria for watershed service conservation and improvement}

Analysis of environmental (vulnerability of water resources) and economic criteria (OCs of watershed service provision) in the Guapi-Macacu watershed allowed us to identify priority areas for watershed service conservation and improvement. These areas are the land usebased management options (i.e. conversion of pastoral or agricultural lands to forest) with the highest potential of improving water quality and lowest OCs (Figure 7).

Our results highlight the sub-watersheds where the vulnerability of water resources are highest and OCs of converting land uses to foster watershed service provision are lowest. The high priority areas (in dark red) are in most cases found in sub-watersheds with steeper average slope levels where impact on water resources was found to be high (Figure 7).

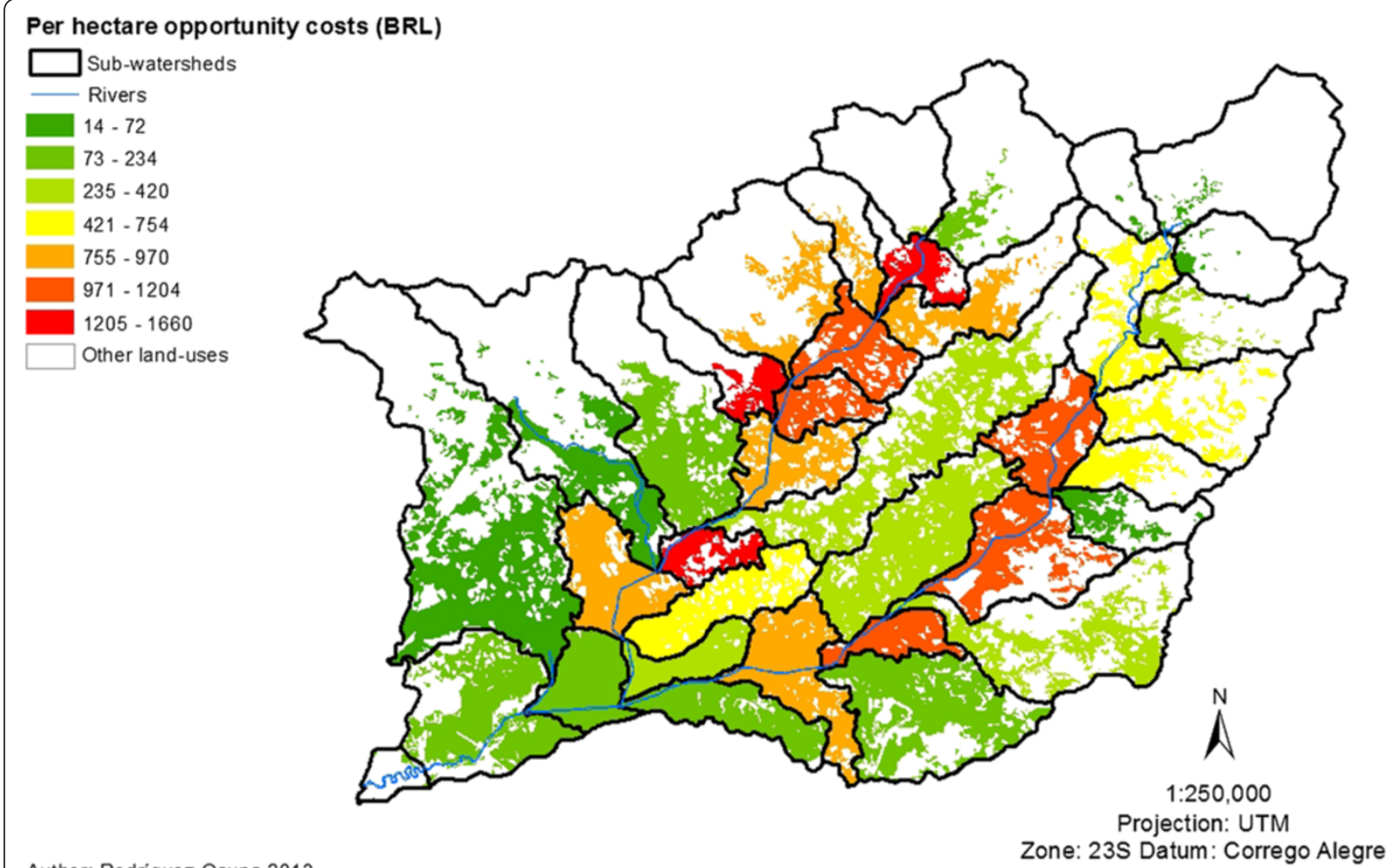

Author: Rodriguez Osuna 2013

Data sources: Ferreira 2012; IBGE 2010;

Naegeli 2010; Pedreira et al. 2009; Fidalgo et al. 2008

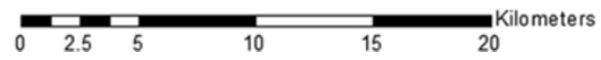

Figure 6 Spatial per hectare opportunity costs in BRL for the land uses "agriculture" and "pasture" within each sub-watershed in the Guapi-Macacu watershed. The white areas within the map correspond to those with land uses other than agriculture in the Guapi-Macacu watershed. 


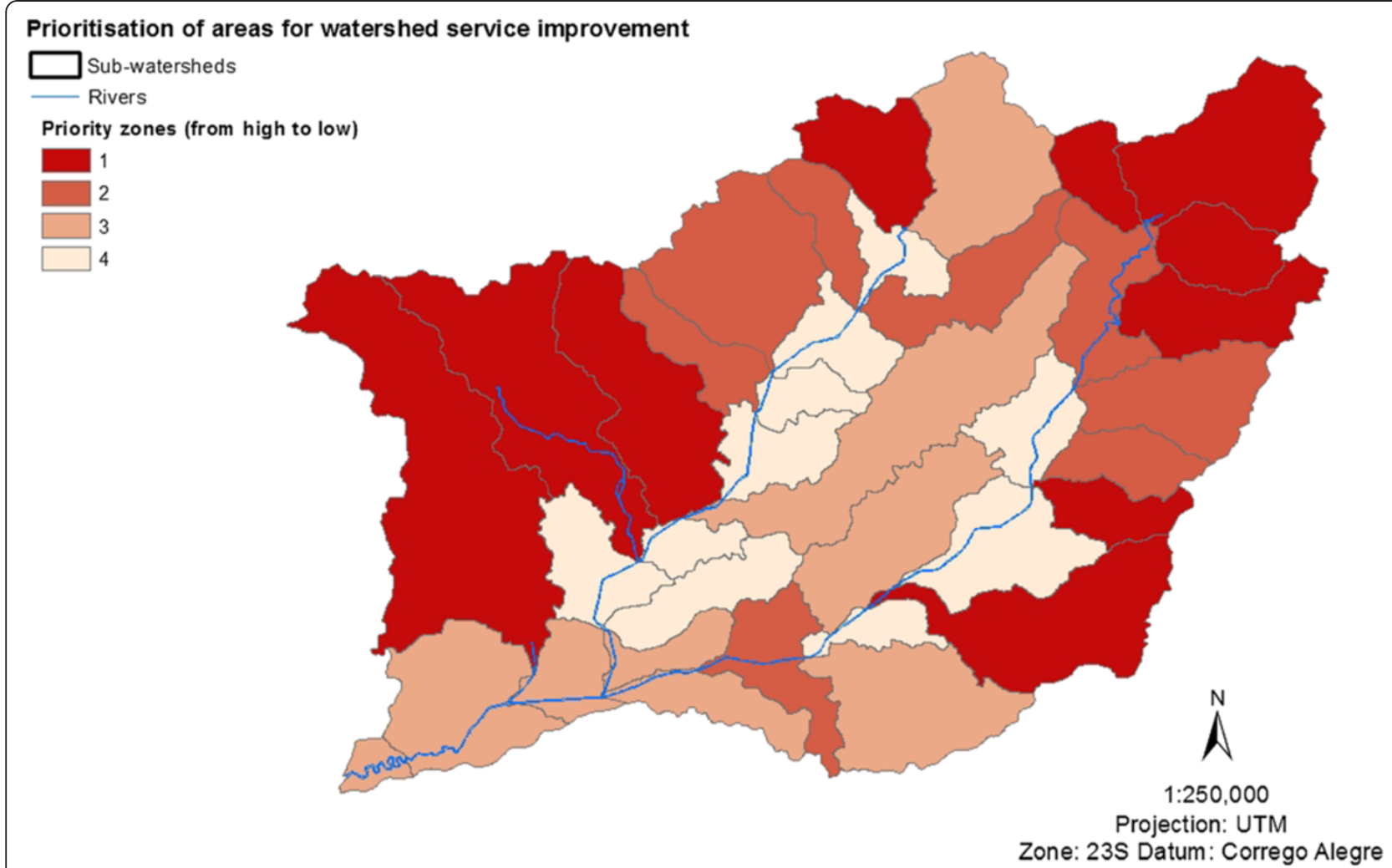

Author: Rodriguez Osuna 2013

Data sources: Ferreira 2012; IBGE 2010

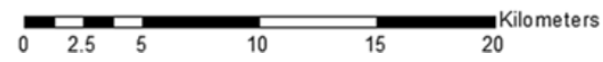

Figure 7 Priority areas for improving or ensuring watershed services of the Guapi-Macacu watershed. Priority areas for improving or ensuring watershed services (water quality) where 1 is considered high and 4 represents low priority.

\section{Demand for watershed services: water treatment}

According to micro-economic theory, we interpret the water utility company's demand for chemicals to treat water as its willingness to pay for a desired water quality level (in this case turbidity under 5 NTU for human consumption). The treatment cost of an additional turbidity unit is thus equivalent to the company's potential willingness to pay for any measure that reduces turbidity by the same amount (see avoided cost method, for example, in Perman et al. 2003).

Based on expert interviews and relevant studies (Medeiros et al. 2011, Reis 2004 and Dearmont et al. 1998), which identified turbidity as the key water quality parameter relevant for water treatment costs, we applied the avoided cost method to the local water utility company. In Table 4, the main characteristics of the water treatment are presented.

Based on data from CEDAE (treatment unit Laranjal) for the period between 1998 and 2011, we estimated the avoided costs of a reduction of $1 \%$ turbidity at $15,510 \mathrm{BRL}$, considering an average volume of treated water of 174,545 cubic metres at an average cost of 22.2 BRL per 1,000 cubic metres (Table 5). The Pearson correlation coefficient for average annual turbidity levels and costs for chemical products in this water utility for the period between 1998 and 2011 was 0.4 . This correlation value is relatively low compared to other studies carried out in Brazil. For example, Reis (2004) calculated a correlation value of 0.7 for seven water treatment units in São Paulo and Cabral de Sousa (2011) found a coefficient of 0.9 when comparing 10 different sub-watersheds and their treatment costs in São Paulo.

Reis (2004) found that chemical treatment costs in water utility units on the Piracicaba River are 12.7 times higher than the cost of treating water from the Cantareira system. This author argues that this finding can be explained by the considerably lower forest cover in the Piracicaba watershed (4.3\%) compared to the Cantareira watershed (27.2\%).

Therefore, the geographical location of forests, as well as land use, soil type, geomorphology and predominant geology are considered relevant factors that influence water quality from headwaters (springs) and water treatment costs for public supply. Nevertheless, Reis (2004) showed that the percentage of forest cover is often a 
Table 4 Characteristics of water treatment utility in the lower catchment part of the Guapi-Macacu watershed in 2011

\begin{tabular}{|c|c|}
\hline Treatment unit: Laranjal - CEDAE & Municipality: São Gonçalo \\
\hline Captivation area from the GMW & $1,263 \mathrm{~km}^{2}$ \\
\hline Forest cover in the watershed & $48.8 \%$ \\
\hline Treatment type & Conventional \\
\hline General treatment phases & $\begin{array}{l}\text { Captivation, sedimentation, coagulation, flocculation, decantation, filtration, } \\
\text { disinfection, water fluoridation and } \mathrm{pH} \text { correction }\end{array}$ \\
\hline Treated water flow & Average flow in $2011,5.35 \mathrm{~m}^{3} \mathrm{~s}^{-1}$ \\
\hline Population supplied with treated water & $2,000,000$ inhabitants \\
\hline General chemical products used & $\begin{array}{l}\text { Aluminium sulphate } \mathrm{Al}_{2}\left(\mathrm{SO}_{4}\right)_{3} \text {, polyelectrolyte, hexafluorosilicic acid } \mathrm{H}_{2} \mathrm{SIF}_{6,} \\
\text { chlorine, calcium oxide } \mathrm{CaO}\end{array}$ \\
\hline Costs with chemical products for the treatment of raw water & $2.31 \times 10^{6}$ BRL (year 2011) \\
\hline Turbidity of raw water, average values & 17.10 NTU \\
\hline \multirow[t]{3}{*}{ Treated water characteristics } & Colour, $2.50 \mathrm{uH}$ \\
\hline & Turbidity, 0.34 NTU \\
\hline & For the treatment of $6 \mathrm{~m}^{3} \mathrm{~s}^{-1}$ \\
\hline \multirow{2}{*}{$\begin{array}{l}\text { Total costs with chemical products and electricity in a year for the } \\
\text { water treatment unit }\end{array}$} & - 300,000 [BRL] (monthly expenditure for chemical products) \\
\hline & $\begin{array}{l}\text { - } 100,000[B R L] \text { (monthly expenditure for electricity in the captivation and } \\
\text { production area within the unit) }\end{array}$ \\
\hline
\end{tabular}

sufficiently informative indicator of watershed health and thus water quality.

Water quality monitoring obtained in seven monitoring campaigns in the years 2010 and 2011 along the whole watershed demonstrated lower turbidity levels in the highest parts of the sub-watershed, where forest cover is higher. For example, our reference sub-watershed Manuel Alexandre presented an average value of $0.8 \mathrm{NTU}$ at the outlet as compared to 17.4 NTU at a lower region close to the water intake point of the water utility (Paiva et al. 2011).

\section{Is paying for land use changes that foster watershed services cheaper than treating water?}

The estimated OCs of converting land use/land cover to the benefit of water quality can range between 4,000 to 5,000 BRL per hectare each year for agricultural systems and less than 100 BRL for pasture land. However, the actual OCs per hectare in many sub-watersheds are likely to be much lower, especially if land close to rivers and headwaters is covered by extensive pastures. On the demand side, we estimate that the water company CEDAE's maximum WTP for land use change in the

Table 5 Annual avoided costs from 1998-2011 for the local water utility company

\begin{tabular}{|c|c|c|c|}
\hline $\begin{array}{l}\text { Average } \\
\text { quantity } \\
\left(\mathrm{m}^{3} \mathrm{yr}^{-1}\right)\end{array}$ & 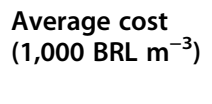 & $\begin{array}{l}\text { Total cost } \\
\text { (BRL) }\end{array}$ & $\begin{array}{l}\text { Avoided cost } \\
\text { for } 1 \% \text { of turbidity } \\
\text { reduction (BRL) }\end{array}$ \\
\hline $174,545.3$ & 22.2 & $3,877,482.0$ & $15,509.9$ \\
\hline
\end{tabular}

watershed based on avoided costs is 15,510 BRL per additional $1 \%$ reduction in turbidity levels at the water intake point of the water utility.

Ideally, a full-scale hydrological model for the watershed would provide us with the potential effect of alternative land use scenarios on turbidity at the water intake point of the water utility. In the absence of such a model, we can only provide an informed estimation with regard to the viability of PWS in the watershed. At the high OCs end, it is clearly unrealistic to expect that the conversion of less than 3 hectares of intensively used cropland in the whole watershed (the avoided cost of water quality reduction: 15,510 BRL / maximum per hectare OC: 5,482.5 BRL per ha $=2.83$ ha) will result in a $1 \%$ reduction of turbidity levels. In contrast, carefully selected pasture and low intensity agricultural sites could potentially be converted into forest (162 to 814 hectares) in the case of pastures. Land use changes at that scale are more likely to bring about measurable changes in turbidity levels if located in zones with a large impact on river water quality.

Unfortunately, given the spatial distribution of pastures and high intensity agriculture in the watershed, there are likely to be limited opportunities to convert large tracts of land at low costs. Payments for forest recuperation may thus likely remain a complementary watershed management measure in our study area. As an alternative to full scale conversion, some simple pasture management techniques, such as limiting access of cattle to the riverbed in lowland pastures (see dark red areas in the centre of Figure 7), could prove to be 
comparatively low cost and highly effective measures to reduce turbidity levels close to the water intake point of CEDAE.

Inadequate livestock grazing practices can compromise water quality to the point where is considered degraded and highly polluted and not able to meet water quality standards (EPA 2013). Therefore, excluding livestock from streams and improving range management practices can contribute to reduce turbidity on streams (EPA 2013).

Although the water supply company's WTP does not match the estimated OCs, payments from other water users are an additional option that can be taken into account in the design of a PWS scheme in this watershed. Particularly important would be the demand of water by COMPERJ (the Rio de Janeiro petrochemical complex). In addition, this assessment was solely carried out on the basis of water quality improvements in terms of turbidity levels, since it was found this service to be relevant for the demanders downstream. However, accounting for additional ecosystem services provided by forest ecosystems would increase the potential WTP for ecosystem services in this region.

\section{Discussion}

This study estimated the costs involved in both supply and demand of water quality maintenance and improvement; where we identified priority areas for supply in order to target watershed management measures or support the launch of compensation schemes such as PES or PWS. We estimated demand by assessing the willingness to pay for a water quality improvement in terms of turbidity by the main watershed user, the state water utility company (CEDAE). This approach showed to be helpful for the design of watershed payment schemes in other local contexts (Pagiola et al. 2010, Martinez de Anguita et al. 2011, Garcia-Nieto et al. 2013, MartinOrtega et al. 2012). Adjusting off-the-shelf modelling packages, such as SWAT, for our purposes (see for example, Martinez de Anguita et al. 2011 and Quintero et al. 2009), was deemed inappropriate by local hydrologists. Attributing water quality dynamics to land use changes is one of the most challenging issues in ecosystem services research (De Groot et al. 2010). Since we lack an appropriate hydrological model, we have left the quantification of the effects of specific land use changes on water quality improvement in our study area for future research.

Some limitations of this study are related to the use of turbidity as a water quality indicator. Land use is most likely the most relevant factor that influence turbidity changes in streams (ECI 2014). However, turbidity is subject to natural physical and biological variations even if the watershed is forested. The physical factors relate particularly to erosion processes, landslides, and mudslides after heavy rainfalls. These accelerated slope processes that are associated with high sediment loads and turbidity can even take place under closed forest cover, as seen for example during the 2011 mudslides and floods (Nehren et al. 2014). The nature of soils and geology in the watershed (e.g. erosion of the riverbed) also determines how easily erosion might occur (ECI 2014).

We found a lower correlation between water treatment costs and turbidity (0.4) than the 0.7 found by Reis (2004) in her analysis of 7 treatment utility plants in São Paulo. The use of average values for turbidity and the costs of chemicals used for treatment would most likely mask a higher correlation. However, our correlation is relevant since it supports our conclusion that the WTP from the water supply company is likely to be rather low. Yet, turbidity levels monitored at the water intake point of the water supply facility do not exceed 50 NTU (Paiva et al. 2011).

Comparing these turbidity levels for water treatment with other cases in Brazil, we found mean turbidity levels of 16 NTU and 64 NTU in São Paulo (the first value between April to October and November to March respectively) at the water intake point of the River Piracicaba. In this particular case, it was found that this treatment plant had the highest costs related to the use of chemical products for water treatment, which in addition might have been correlated with the low forest cover of 4.3\% (Reis 2004). During these same periods mean turbidity in the Cantareira system (dam) varied from 3-9 NTU respectively with the lowest costs for chemical products with a more elevated forest cover 27.1\% (Reis 2004).

However, with regards to the use of chemical products for water treatment and their relative costs, it should be noted that not all chemical products are used to tackle turbidity. The main product used to flocculate suspended material and reduce turbidity is aluminum sulphate, which has the highest share of the cost of chemicals for the treatment process. The use of the other single chemical products is also correlated to the performance of the treatment process, where, for example the better the quality of the final product (i.e. treated/filtered water), the lower the cost with the rest of the chemical products, namely hexafluorosilicic acid, chlorine and calcium oxide.

Agricultural land use clearly represents the most important entry point for watershed managers in the studied area, which is why we focused on quantifying the OCs of changing rural land cover. It should be noted that Lorz et al. (2011) demonstrated that urban settlements also negatively impact water quality in terms of turbidity, ammonium $\left(\mathrm{NH}_{4}^{+}\right)$and Chemical Oxygen Demand (COD). Therefore, future studies should also consider the costs of changes to waste water treatment in upstream urban settlements. 
Moreover, we note that the land cover classification used in our analysis does not distinguish between agricultural production systems and underestimates the total land under production due to low resolution (Pedreira et al. 2009; Fidalgo et al. 2008). Land use classifications with higher resolution (based on SPOT 5) only exist for the upper part of the Guapi-Macacu watershed, but such data would permit our OC analyses to be extrapolated in more detail.

Comparing our OC estimates to actual transfers in existing PWS schemes in the Atlantic Forest, we find that per hectare payment values range from $10 \mathrm{BRL}$ annually to 566 BRL monthly (Veiga and Galvadao 2011). These include annual per hectare payments of 176 BRL in the municipality of Extrema, state of Minas Gerais; 25-125 BRL in the watershed of PCJ in the state of São Paulo; 10-60 BRL in the watershed of Guandu, state of Rio de Janeiro; 80-340 BRL in the watershed Benevente, state of Espírito Santo; 80-340 BRL in the Guandu watershed, states of Espírito Santo and Rio de Janeiro; 75-563 BRL paid by the OASIS Foundation, states of Espírito Santo and Paraná; and 175-577 BRL monthly payments in the state of Santa Catarina (Veiga and Galvadao 2011).

At the regional level in Latin America, we can compare our estimates to well-known schemes, such as the Costa Rican PES programme (FAO 2007). Here, annual per hectare payments vary from 98 BRL for natural regeneration to $152 \mathrm{BRL}$ for forest preservation and more than 2,332 BRL for new forest plantations for a time period over five years (Ecosystem Marketplace 2010). The National Programme for Hydrological Environmental Services in Mexico (PSAH) pays between 57-90 BRL per hectare annually depending on the forest type considering the OCs of land conversion (Ecosystem Marketplace 2010; Muñoz-Piña et al. 2008). The Ecuadorian PWS Programme in Pinampiro pays landowners around 14-29 BRL per hectare annually (Wunder and Alban 2008), while the Los Negros programme in Bolivia pays in-kind with beehive boxes for honey production (Asquith and Wunder 2008). Agricultural OCs in our study area thus clearly exceed the average annual payment in existing PWS schemes by more than a factor of 10 .

However, we note that payments made under the above mentioned schemes may focus in other actions other than conversion from agriculture or pastoral lands into forest. In the case of the Atlantic Forest schemes, mostly payments are directed to protect headwater areas and restore and conserve riparian forests. However, actions other than conversion from agriculture or pastoral lands into forest can be paid for (eg. soil conservation practices). The price paid to farmers in the PSAH Mexican scheme has been decided based on the assumption that corn production would be an alternative to conservation (Ecosystem Marketplace
2010). The Pinampiro PWS programme pays for forest and páramo protection and regeneration (Wunder and Alban 2008), while the Los Negros programme compensates for avoided deforestation of cloud forests (IIED 2012b).

Our results may prove useful for ongoing watershed conservation initiatives, such as the World Bank funded Rio Rural carried out by the State Secretary for Agriculture and Livestock in the state of Rio de Janeiro (RioRural 2013). This and many other initiatives in the Atlantic Forest region have shown great interest in incentive-based watershed management approaches. Furthermore, Brazilian legislation has been supporting such approaches, such as the Brazilian National Law on Water Resources (Law 9433/1997), which allows for example the establishment of watershed service markets and permits charging for water use as it is taking place in some watersheds in Rio de Janeiro (Veiga 2008).

Equally relevant is the more recent Law 9985/2000 "SNUC" that adopts the protector-receiver principle, which allows for rewards in exchange for good natural resource stewardship (Strobel et al. 2007). Funding for incentive-based watershed management may be derived from Brazil's "ecological" tax system, which compensates municipalities for conservation costs based on the valueadded tax (ICMS) (Marques 2009; Veiga 2008).

In addition, the decree No. 42029/2011 established the Payment for Environmental Services mechanism under the Rio de Janeiro State Programme for Conservation and Revitalization of Water Resources (PROHIDRO). This decree has given legal status to the PES Programmes already underway in the state of Rio de Janeiro, such as the Lagos São João Committee through Good Practices Fund (Funboas) and Guandu Committee through Water and Forest Programme implemented in the municipality of Rio Claro.

This study can potentially contribute to implementation of these laws in the Guapi-Macacu watershed in a more effective way with respect to social, economic and environmental aspects. Given that our study results take into account these different aspects and are based on primary data obtained in the watershed, our study can contribute by identifying limitations and opportunities related to economic watershed compensation programmes.

\section{Conclusions}

Assessing the economic scope of incentive-based watershed management requires knowledge of both the costs of providing additional watershed services through land use and land cover change (service supply) and the willingness to pay (demand) for such services. This study has quantified these two necessary inputs to enable an informed decision-making process in the context of the Guapi-Macacu watershed in the state of Rio de Janeiro, Brazil. 
With regard to supply, we found that land users' OCs range between 972-5,482 BRL per hectare for cropland and $<100$ BRL per hectare for pastures. At the subwatershed level, zones that use a high proportion of pasture but low proportion of cropland in the land use mix will accordingly have low area-weighted average OCs and vice versa. With regard to demand, we assessed water treatment costs and found a $1 \%$ reduction in water turbidity levels to be worth $15,510 \mathrm{BRL}$ on average to the water company, CEDAE.

In absolute terms, only a relatively small share of land in the watershed is cropland (5,560 hectares); the area covered by pasture $(52,374 \mathrm{ha})$ and forest $(61,665 \mathrm{ha})$ is much larger. However, cropland covers a considerable amount of land with potential to provide watershed services and, as a result, high OCs become a critical limitation on strategies that aim to change land use for the benefit of water quality.

Nevertheless, given the spatial distribution of pastures and high intensity agriculture in the watershed, we find that payments for forest recuperation are likely to be cost-effective in sub-watersheds with a high proportion of pasture land. Some of these sub-watersheds also happen to exhibit high levels of water resources vulnerability and thus represent potential priority intervention zones for watershed management (Figure 6). In these areas, watershed planners may reap considerable benefits from active pasture management options, such as silvopastoral systems or strategic fencing of riparian areas. In addition, sustainable agricultural and soil conservation practices can bring additional benefits in terms of reducing and avoiding sedimentation, erosion, which in turn result in improving water quality.

To the extent that smallholders in the study area also depend on subsistence production for their livelihoods, land use based watershed management strategies will have to also consider food security issues, especially in the upper part of the watershed.

Our study area reflects watershed management issues that are typical across many parts of the Atlantic Forest region, which often have diverse agricultural mosaics and thus highly variable OCs. Wherever intensively used cropland dominates in the vulnerable zones of large watersheds, land use planners will find it difficult to rely on the use of payments for watershed services alone. Effective watershed management will then have to be combined with enhanced monitoring and enforcement activities to ensure that the Brazilian Forest Law is complied with, particularly with regard to riparian forests. Research designed with a bottom-up approach that quantifies the potential compliance costs of land users can clearly help policy makers to target both incentives and disincentives in a cost-effective manner.

\section{Competing interests}

The authors declare that they have no competing interests.

\section{Authors' contributions}

VRO undertook the field work, carried out the analysis and wrote the manuscript under her PhD thesis at the University of Leipzig. JB and RBP supported the conception of the research design and data analysis. JB, RBP and UN reviewed and commented on various versions on this manuscript. UN provided insights on ecosystem management aspects. $\mathrm{HG}$ and $\mathrm{JH}$ contributed to the overall research design and gave valuable comments on aspects related to farming systems analysis and landscape ecology (respectively). All authors read and approved the final manuscript.

\section{Authors' information}

Vanesa Rodríguez Osuna is an Environmental Engineer with a M.Sc. Degree in Natural Resource Management and Technologies in the Tropics and Subtropics, currently finalising her PhD in Geography at the University of Leipzig, Germany. She is a Senior Researcher at the Center for Development Research (ZEF, University of Bonn, Germany) and the Cologne University of Applied Sciences. Her research areas include ecosystem services, climate change and integrated land and water resources management. Jan Börner is an agricultural and environmental economist with a Masters in International Agricultural Sciences and a PhD in Agricultural Science. He is a Professor for Economics of Sustainable Resource Use at ZEF (University of Bonn, Germany), where he leads a research group focusing on the analysis of environmental and conservation policy tools for tropical forest conservation. Udo Nehren is a physical geographer with a Masters in Engineering and a PhD in Geography. He is a senior researcher and lecturer in landscape ecology at Cologne University of Applied Sciences, Germany. His research areas include quaternary landscape evolution, landscape vulnerability and resilience and ecosystem management with a strong focus on tropical environments. Rachel B. Prado is a Biologist with a PhD in Environmental Engineering Science. She is currently working as a Research Scientist, focused on geotechnologies applied at environmental monitoring and management at Embrapa Soils, Rio de Janeiro, Brazil. Her research areas include water resources monitoring, watershed management and water ecosystem services modeling. Hartmut Gaese is an Agricultural Engineer with specialisation on farming systems in the tropics and subtropics and irrigation systems. He is a former Director of the Institute of Natural Resource Management and Technologies in the Tropics and Subtropics (ITT) at Cologne University of Applied Sciences, Germany. Jürgen Heinrich is a Physical Geographer with a PhD in Geography. He is a Professor in Geography at the University of Leipzig, Germany. His research focuses on geomorphology, quaternary geology, soil science, plant geography, geoecology and environmental research.

\section{Acknowledgement}

The authors acknowledge financial support of the IPSWAT Programme (financed from the German Federal Ministry of Research-BMBF) and the DINARIO Project: "Climate Change, Landscape dynamics, Land use and Natural Resources in the Atlantic Forest of Rio de Janeiro". We thank the support of the Team of Researchers of MP2 Embrapa Soils of Rio de Janeiro and DINARIO. In our study region, we specially thank Lenilson Biazatti (from the Rural Workers Union), Nicholas Locke (REGUA Association Director), Thabta Matos de Mata from the City Council of Cachoeiras de Macacu, Jocemir Da Silva (Chief technical extension officer of EMATER in Cachoeiras de Macacu), Demerval Pereira de Sousa (President of A.L.A.F.), technical staff from the state water utility company (CEDAE - Imunana Laranjal) and all farmers who enriched this study with their valuable time. We are also very grateful for the proofreading of this text by Dr. Kylie Quinn and Meghan Doiron.

\section{Author details}

${ }^{1}$ Center for Development Research (ZEF), Department of Economic and Technological Change, University of Bonn, Walter-Flex-Str. 3, 53117 Bonn, Germany. ${ }^{2}$ Institute for Technology and Resources Management in the Tropics and Subtropics (ITT), Cologne University of Applied Sciences, Betzdorfer Str. 2, 50679 Cologne, Germany. ${ }^{3}$ Empresa Brasileira de Pesquisa Agropecuária (EMBRAPA Soils), Brazilian Enterprise for Agricultural Research, Geotechnologies and Environmental Monitoring, Rua Jardim Botânico, CEP 22460-000 Rio de Janeiro, Brazil. ${ }^{4}$ Institute for Geography, Department of Physical Geography, University of Leipzig, Johannisallee 19a, 04103 Leipzig, Germany. 
Received: 5 February 2014 Accepted: 22 May 2014 Published online: 08 August 2014

\section{References}

Angelsen A, Larsen HO, Lund J (2011) Measuring livelihoods and environmental dependence: Methods for research and fieldwork. Routledge, London

Arriagada RA, Ferraro PJ, Sills EO, Pattanayak SK, Cordero-Sancho S (2012) Do payments for environmental services affect forest cover? A farm-level evaluation from Costa Rica. Land Econ 88(2):382-399

Asquith N, Wunder S (2008) Payments for Watershed Services. The Bellagio Conversations. Fundación Natura Bolivia, Bolivia

Balvanera P, Uriarte M, Almeida-Lenero L, Altesor A, DeClerck F, Gardner T, Hall J, Lara A, Laterra P, Pena-Claros M, Silva Matos DM, Vogl AL, Romero-Duque LP, Arreola LF, Caro-Borrero AP, Gallego F, Jain M, Little C, de Oliveira XR, Paruelo $J M$, Peinado JE, Poorter L, Ascarrunz N, Correa F, Cunha-Santino MB, Hernandez-Sanchez PA, Vallejos M (2012) Ecosystem services research in Latin America: The state of the art. Ecosystem Services 2:56-70

Batchelor C, Cain J, Farquharson F, Roberts J (eds) (1998) Improving Water Utilization from a Catchment Perspective, vol 4. SWIM Paper. International Water Management Institute, Colombo, Sri Lanka

Beets WC (1990) Raising and Sustaining Productivity of Smallholder Farming Systems in the Tropics. A Handbook of Sustainable Agricultural Development. A Handbook of Sustainable Agricultural Development. AgBe Publishing, Holland

Bennett G, Carroll N, Hamilton K (2013) Charting New Waters. State of Watershed Payments. Forest Trends, Washington

Boerner J, Vosti S (2012) Managing Tropical Forest Ecosystem Services: An Overview of Options. In: Muradian R, Rival L (eds) Governing the Provision of Ecosystem Service, vol 4. Springer, pp 21-46, http://www.springer.com/ environment/environmental+management/book/978-94-007-5175-0

Borja A, Galparsoro I, Solaun O, Muxika I, Tello EM, Uriarte A, Valencia V (2006) The European Water Framework Directive and the DPSIR. A methodological approach to assess the risk of failing to achieve good ecological status. Estuar Coast Shelf Sci 66(1):84-96

Calder I (2005) Blue revolution: Integrated land and water resources management $2^{\text {nd }}$ edition. Earthscan, London

CEPF (2001) Perfil do Ecossistema Mata Atlantica, Hotspot de Biodiversidade - Brazil. Critical Ecosystem Partnership Fund

Costanza R, d'Arge R, de Groot R, Farber S, Grasso M, Hannon B, Limburg K, Naeem S, O'Neill RV, Paruelo J, Raskin RG, Sutton P, van den Belt M (1997) The value of the world's ecosystem services and natural capital. Nature 387 (1):253-260

Daily GC, Matson PA (2008) Ecosystem services: From theory to implementation. Proc Natl Acad Sci 105(28):9455-9456

de Cabral Sousa WJ (2011) Pagamento por Servicos Ecossistemicos: Mata Ciliar, Erosao, Turbidez e Qualidade de Agua: Produtos Tecnicos 1. Projeto de Recuperacao de Matas Ciliares, Brazil., Available via Governo do Estado São Paulo www.ambiente.sp.gov.br/mataciliar Accesed 12 Jun 2010

De Groot RS, Wilson MA, Boumans RM (2002) A typology for the classification, description and valuation of ecosystem functions, goods and services. Ecol Econ 41(3):393-408

De Groot RS, Alkemade R, Braat L, Hein L, Willemen L (2010) Challenges in integrating the concept of ecosystem services and values in landscape planning, management and decision making. Ecol Complex 7(3):260-272

Dean W (1997) With Broadax and Firebrand: The Destruction of the Brazilian Atlantic Coastal Forest. University of California Press, United States of America

Dearmont D, McCarl BA, Tolman DA (1998) Costs of water treatment due to diminished water quality: a case study in Texas. Water Resour Res 34(4):849-853

Dudley N, Stolton S (2003) Running Pure: The Importance of Forest Protected Areas to Drinking Water, The Arguments for Protection Series. World BankWWW Alliance for Forest Conservation and Sustainable Use, United Kingdom, http://assets.panda.org/downloads/runningpurereport.pdf. Accessed 10 Jan 2011

ECI (2014) Chapter 3 - Streams. In: Total Suspended Solids and Turbidity in Streams. Department of Ecology, State Washington, http://www.ecy.wa.gov/ programs/wq/plants/management/joysmanual/streamtss.html accessed 7 may 2014

Ecosystem Marketplace (2010) Water Market: Mexico Payment for Hydrological Services. Ecosystem Marketplace: A Forest Trends Initiative. The Katoomba Group., http://www.ecosystemmarketplace.com/pages/dynamic/web.page. php?section=water_market\&page_name=crwb_market. Accessed 13 Sep 2011

Engel S, Pagiola S, Wunder S (2008) Designing payments for environmental services in theory and practice: An overview of the issues. Ecol Econ 65(4):663-674

EPA (2013) Total Maximum Daily Loads (TMDLs) at Work: Arizona. Committed Landowner Implements and Advocates Improved Grazing Practices in Nutrioso Creek, Reducing Turbidity Levels to Attain Water Quality Standards. United States Environmental Protection Agency, http://water.epa.gov/ lawsregs/lawsguidance/cwa/tmdl/nutriosocreek.cfm. Accessed 5 May 2014

FAO (2007) The State of Food and Agriculture: Paying Farmers for Environmental Services. Food and Agriculture Organization of the United Nations, Rome

Farber S, Costanza R, Childers DL, Erickson J, Gross K, Grove M, Hopkinson CS, Kahn J, Pincetl S, Troy A (2006) Linking ecology and economics for ecosystem management. Bioscience 56(2):121-133

Ferreira CEG (2012) Sistema de Suporte a Decisao Espacial Aplicado a Analise da Vulnerabilidade dos Recursos Hidricos na Bacia Guapi-Macacu, Master Thesis. Universidade Estadual do Rio de Janeiro, Rio de Janeiro, Brazil

Fidalgo E, Pedreira B, Abreu MD, Moura ID, Godoy M (2008) Uso e Cobertura da Terra da Bacia Hidrografica do rio Guapi-Macacu, Serie Documentos 105. Embrapa Solos, Brazil, ISSN 1517-262

Forero FA (2002) Sistemas de producción rurales en la Región Andina colombiana: análisis de su viabilidad económica, ambiental y cultural. Grupo Sistemas de Producción y Conservación/ Instituto de Estudios Rurales (IER), Bogota, Colombia

Gaese H (2009) Demands for Interdisciplinary Research in Human-Ecological Systems. In: Gaese H, Torrico JC, Wesenberg J, Schluter S (eds) Biodiversity and Land Use Systems in the Fragmented Mata Atlantica of Rio de Janeiro. Cuvillier Verlag, Gottingen, Germany

Garcia-Nieto AP, Garcia-Llorente M, Iniesta-Arandia I, Martin-Lopez B (2013) Mapping forest ecosystem services: From providing units to beneficiaries. Ecosystem Services 4(Special Issue on Mapping and Modelling Ecosystem Services):126-138

Grieg-Gran M, Porras I, Wunder S (2005) How can market mechanisms for forest environmental services help the poor? Preliminary lessons from Latin America. World Dev 33(9):1511-1527

Guedes FB, Seehusen SE (2011) Pagamentos por Servicos Ambientais na Mata Atlanica: licoes aprendidas e desafios, vol 2, Serie Biodiversidade 42. Ministerio do Meio Ambiente-MMA, Brasilia, Brazil

Haines-Young R, Potschin M (2013) Proposal for a Common International Classification of Ecosystem Goods and Services (CICES) for Integrated Environmental and Economic Accounting, Report to the European Environment Agency., Available via CICES. http://cices.eu/wp-content/uploads/2012/07/ CICES-V43_Revised-Final_Report_29012013.pdf Access 21 Jul 2011

Hanson C, Talberth J, Yonavjak L (2011) Forests for Water: Exploring Payments for Watershed Services in the U.S. South. World Resources Institute, WRI Issue Brief. Available via WRI. http://www.wri.org/publication/forests-water. Accessed 04 Jul 2014

Hawkins K (2003) Economic Valuation of Ecosystem Services. University of Minnesota, http://www.environmentalmanager.org/wp-content/uploads/ 2008/04/valuation\%2520of\%2520ecosystems.pdf. Accessed 04 Jul 2014

Holmes TP (1988) The offsite impact of soil erosion on the water treatment industry. Land Econ 64(4):356-366

Honey-Roses J, Acuna V, Bardina M, Brozovi N, Marce R, Munne A, Sabater S, Termes M, Valero F, Vega L, Schneider DW (2013) Examining the Demand fo Ecosystem Services: The Value of Stream Restoration for Drinking Water Treatment Managers in the Llobregat River, Spain, vol 90:196.205. Elsevier BV

IIED (2012a) Paying for Watershed Services: An Effective Tool in the Developing World, IIED Briefing Papers., Available via IIED http://pubs.iied.org/17128IIED. Accessed 27 Aug 2012

IIED (2012b) Compensation for Hydrological Environmental Services in Los Negros Cloud Forest. Payments for Watershed Markets-Information on Schemes in Developing Countries., Available via IIED http://www.watershedmarkets.org/casestudies/Bolivia_Los_Negros_E.html. Accessed 24 Mar 2014

Instituto Terra Mater (2009) Relatório da Análise de Percepção Ambiental e sobre Pagamentos por Serviços Ambientais nas Microbacias do Moinho e Cancan. Produto 3. Serviços de monitoramento sócioconômico e de percepção ambiental em microbacias piloto - "Projeto de pagamento de serviços ambientais". Contrato no PRMC/GEF/BIRD, Piracicaba, Brazil

López A (1997) Análise dos Custos Privados e Sociais da erosão do solo- o caso da bacia do Rio Corumbatai, Doctoral Thesis. Escola Superior de Agricultura "Luiz de Queiroz" (ESALQ), University of São Paulo (USP), Piracicaba 
Lorz C, Abbt-Braun G, Bakker F, Borges P, Bornick H, Frimmel FH, Gaffron A, Hebben N, Hofer R, Makeschin F, Neder K, Roig HL, Steiniger B, Strauch M, Walde D, Weis H, Worch E, Wummel I (2011) Die Bedeutung von Landnutzungsanderungen fur ein Integriertes WasserressourcenManagement. Eine Fallstudie aus dem westlichen Zentral-Brasilien. Fachberichte Wasserversorgung. Fachberichte Wasserversorgung, Vulcan Verlag, Essen, Germany, gwf-Wasser Abwasser

Marques FM (2009) Valoracao dos Servicos Ambientais da Floresta de Mata Atlantica associados a Qualidade e Quantidade da Agua na APA do Sana. Curso de Pos-Graduacao em Agronomia Ciencia do Solo, Thesis. Seropedica, Universidade Federal Rural do Rio de Janeiro (UFRRJ), Rio de Janeiro, Brazil

Martinez de Anguita P, Rivera S, Beneitez JM, Cruz F, Espinal FM (2011) A GIS cost-benefit analysis-based methodology to establish a payment for environmental services system in watersheds: application to the Calan River in Honduras. J Sustain For 30(1-2):79-110

Martin-Ortega J, Ojea E, Roux C (2012) Payments for Water Ecosystem Services in Latin America: Evidence from Reported Experience. In: TEEB Conference 2012. Mainstreaming the Economics of Nature: Challenges for Science and Implementation, Leipzig, Germany., p ID143

MDA (2010) Programa Nacional de Crédito Fundiário (PNCF). Linha de Financiamento combate à pobreza rural, Manual de operações. Ministry of Agrarian Development (MDA). Secretaria de Reordenamento Agrario, Brasilia, Brazil

MEA (2005) The Millenium Ecosystem Assessment. Island Press, Washington D.C

Medeiros R, Young CEF, Pavese HB, Araujo FFS (2011) Contribuição das unidades de conservação para a economia nacional: Sumário Executivo. UNEP-WCMC, Brasilia, Brazil

Ministry of Environment (2005) Rio Floresta. Assistencia Tecnica e extensao florestal aos agricultores familiares da Mata Atlantica do Estado do Rio de Janeiro. Bases Legais e tecnicas para implantacao de projetos florestais. Ministry of Environment Niteroi, Rio de Janeiro, Brazil

Montes C (2007) Del desarrollo sostenible al servicio de los ecosistemas. Asociacion Espanola de Ecologia Terrestre. Ecosistemas Revista Cientifica y Tecnica de Ecologia y Medio Ambiente 16(3). Available via RUA.http://rua.ua. es/dspace/handle/10045/7641?locale=en. Accessed 04 Jul 2014

Moore W, McCarl B (1987) Off-site costs of soil erosion: A case study in the Willamette Valley. West J Agric Econ 12(1):42-49

Muñoz-Piña C, Guevara A, Torres JM, Braña J (2008) Paying for the hydrological services of Mexico's forests: Analysis, negotiations and results. Ecol Econ 65 (4):725-736

Naegeli F (2010) Evaluation of Forest Fragmentation and Land Use Change Patterns using Remote Sensing Techniques and Field Methods, Master Thesis. Cologne University of Applied Sciences, Abstract available via DINARIhttp://dinario.fh-koeln.de/2011/F.\%20Naegeli-\%20Evaluation\%20of\% 20forest\%20fragmentation\%20and\%20land\%20use.pdf. Accessed 04 Jul 2014

Nehren U, Kirchner A, Sattler D, Turetta AP, Heinrich J (2013) Impact of natural climate change and historical land use on landscape development in the Atlantic Forest of Rio de Janeiro, Brazil. An Acad Bras Cienc 85(2):497-518

Nehren U, Sudmeier-Rieux K, Sandholz S, Estrella M, Lomarda M, Guillén T (eds) (2014) The Ecosystem-based Disaster Risk Reduction Case Study and Exercise Source Book. UNEP/CNRD, http://postconflict.unep.ch/publications/DRR CASE_STUDIES_\&_EXERCISES.pdf. Accessed 04 Jul 2014

Pabon-Zamora L, Fauzi A, Halim A, Bezaury-Creel J, Vega-Lopez E, Leon F, Gil L, Cartaya V (2008) Protected Areas and Human Well-Being: Experiences from Indonesia, Mexico, Peru and Venezuela, vol CBD Technical Series No. 36. Secretariat of Convention on Biological Diversity, Montreal

Pagiola S, von Ritter K, Bishop J (2004) Assessing the Economic Value of Ecosystem Conservation, Environment Department Paper No. 101. The World Bank Environment Department, Washington, United States of America, Available via CBD. https://www.cbd.int/doc/case-studies/inc/cs-inc-iucn-ncwb-en.pdf. Accessed 04 Jul 2014

Pagiola S, Zhang W, Colom A (2010) Can payments for watershed services help finance biodiversity conservation? A spatial analysis of Highland Guatemala. J Nat Resour Pol Res 2(1):7-24

Paiva M, Penedo S, Kuenne A, Prado RB, Schuler AE (2011) Qualidade da Agua e Exportacao de Sedimentos em Sub-bacias dos rios GuapiMacacu- Bioma Mata Atlantica- RJ. In: XXXIII Congresso Brasileiro de Ciencia do Solo. Solos nos Biomas Brasileiros: Sustentabilidade e Mudancas Climaticas. Embrapa, Uberlandia /Minas Gerais, Brazil, Available via Embrapa. http://ainfo.cnptia.embrapa.br/digital/bitstream/item/51926/ 1/2315-1.pdf. Accessed 04 Jul 2014
Pattanayak SK, Wunder S, Ferraro PJ (2010) Show me the money: Do payments supply environmental services in developing countries? Rev Environ Econ Policy 4(2):254-274

Pedreira B, Fidalgo ECC, Abreu MB, Epiphanio JCN, Galvao LS (2009) Mapeamento do uso e cobertura da terra da bacia hidrografica do rio Guapi-Macacu, RJ. Anais XIV Simposio Brasileiro de Sensoriamento Remoto. Natal, INPE. pp 2111-2118

Perman R, Ma Y, McGilvray J, Common M (2003) Natural Resource and Environmental Economics, Third Editionth edn. Pearson Education Limited, Available via WordPress. http://dutraeconomicus.files.wordpress.com/2014/ 01/roger-perman-yue-ma-michael-common-david-maddison-jamesmcgilvray-natural-resource-and-environmental-economics-3rd-edition-2003. pdf. Accessed 04 Jul 2014

Porras I, Grieg-Gran M, Neves N (2008) All that Glitters: A Review of Payments for Watershed Services in Developing Countries, vol Natural Resource Issues 11. International Institute for Environment and Development, Available via IIED. http://pubs.iied.org/13542IIED.html. Accessed 04 Jul 2014

Postel B, Barton H, Jr T (2005) Watershed protection: Capturing the benefits of nature's water supply services. Nat Res Forum 29:98-108

Pria DA, Diederichsen A, Klemz C (2013) Pagamento por Servicos Ambientais. Uma estrategia para a conservacao ambiental nas regioes produtivas do Brasil? Sustentabilidade em. Debate 4(1):317.340

Quintana B (2012) Native Tree Species in Silvopastoral Systems: A Bioeconomic Assessment in Cachoeiras de Macacu, RJ-Brazil, Master Thesis. Master of Science awarded by Universidad Autónoma de San Luis Potosí and Cologne University of Applied Sciences. Cologne University of Applied Sciences. Available. http://www.google.de/url?url=http://comunidadpmpca.uaslp.mx/ documento.aspx\%3FidT\%3D258\& rct=j\&frm=1\&q=\&esrc=s\&sa=U\&ei=z9q2U8KDLOTmywPbw4CgCA\&ved=0CCQQFjAD\&usg=AFQjCNFIdcTMmPEOErr5jbaXkOJOA3FeJA. Accessed 04 Jul 2014

Quintero M, Wunder S, Estrada R (2009) For services rendered? Modeling hydrology and livelihoods in Andean payments for environmental services schemes. For Ecol Manag 258(9):1871-1880

Reis LVS (2004) Cobertura Florestal e Custo do Tratamento de Áquas em Bacias Hidrográficas de Abastecimento Público: Caso do Manancial do Município de Piracicaba, Doctoral Thesis. University of São Paulo (USP), Piracicaba, Accessed via USP. http://www.google.de/url?url=http://www.teses.usp.br/ teses/disponiveis/11/11150/tde-14122004-113308/publico/lucia.pdf\& $r c t=j \&$ frm $=1 \& q=\& e s r c=s \& s a=U \& e i=29 u 2$ U 8 e9FKviywPXg4H4CA\& ved=0CBQQFjAA\&usg=AFQjCNEOmEW_8Ve3hF6ct4kADwlw013bCA. Accessed 04 Jul 2014

Ribeiro MC, Metzger JP, Martensen AC, Ponzoni FJ, Hirota MM (2009) The Brazilian Atlantic Forest: How much is left, and how is the remaining forest distributed? Implications for conservation. Biol Conserv 142(6):1141-1153

RioRural (2013) Rio Rural. Programa de Desenvolvimento Rural Sustentavel em Microbacias Hidrograficas. Governo do Rio de Janeiro. Secretaria de Agricultura e Pecuaria, Rio de Janeiro, Brazil, Available via http://www. microbacias.rj.gov.br/. Accessed 15 Jul 2012

Rodriguez Osuna V (2013) Smallholder Production and Climate Risk: The Lower Amazon Region, Brazil. LAP Lambert Academic Publishing, Germany

Russi D, ten Brink P, Farmer A, Badura T, Coates D, Forster J, Kumar R, Davidson N (2013) The Economics of Ecosystems and Biodiversity for Water and Wetlands. Institute for European Environmental Policy (IEEP) \& Ramsar Secretariat. Available via TEEB. http://www.teebweb.org/publication/the-economics-of-ecosystemsand-biodiversity-teeb-for-water-and-wetlands/. Accessed 04 Jul 2014

Santos DG, Domingues AF, Gisler CVT (2010) Gestão de recursos hídricos na agricultura: O Programa Produtor de Água. In: Prado RB, Turetta AP, Andrade AG (eds) Manejo e Conservação do Solo e da Água no Contexto das Mudanças Ambientais. Brazil, Rio de Janeiro, pp 353-376

Secretary of Agriculture, Cattle Farming, Fisheries and Supply (2011) Government of Rio de Janeiro. Campanha de Vacinalção contra a febre aftosa. Cachoeiras de Macacu Region. Núcleo de Defesa Sanitária- Escritorio Cachoeiras Macacu, Rio de Janeiro, Brazil

Stanton T, Echavarria M, Hamilton K, Ott C (2010) State of Watershed Payments. An Emerging Marketplace. Executive Summary. Ecosystem Marketplace: A Forest Trends Initiative., http://www.forest-trends.org/publication_details.php? publicationID=2440. Accessed 04 Jul 2014

Strobel JS, De Sousa JR WC, da Motta RS, Amend MR, Goncalves DA (2007) Critérios Econômicos para a Aplicação do Princípio do Protetor - Recebedor: Estudo de Caso do Parque Estadual dos Três Picos Serie Tecnica, vol Edicao 11. Conservation Strategy Fund, Brazil 
TEEB (2009) The Economics of Ecosystems and Biodiversity for National and International Policy Maker. Summary: Responding to the Value of Nature. The Economics of Ecosystems and Biodiversity (TEEB), Wesseling, Germany TEEB (2010a) The Economics of Ecosystems and Biodiversity (TEEB). Ecological and Economic Foundations, Earthscan, London and Washington

TEEB (2010b) Mainstreaming the Economics of Nature: A Synthesis of the Approach, Conclusions and Recommendations of TEEB. The Economics of Ecosystems and Biodiversity (TEEB), Malta

TEEB (2010c) TEEB for Business Report, Executive Summary. The Economics of Ecosystems and Biodiversity (TEEB), Malta

Thomas JM, Callan SJ (2010) Economia Ambiental: Aplicacoes, Politicas e Teoria. Cencage Learning, São Paulo

van Noordwijk M (2005) RUPES typology of environmental service worthy of reward, RUPES Working Paper. ICRAF-Southeast Asia, Bogor

Veiga FC (2008) A Construcao dos Mercados de Servicos Ambientais e suas Implicacoes para o Desenvolvimento Sustentavel no Brasil, Doctoral Thesis. UFRRJ, Rio de Janeiro, Brazil

Veiga FC, Galvadao M (2011) Iniciativas de PSA de conservacao dos recursos hidricos na Mata Atlantica. In: Guedes BF, Seehusen ES (eds) Pagamentos por Servicos Ambientais na Mata Atlanica: licoes aprendidas e desafios, vol Serie Biodiversidade 42, Secondth edn. Ministerio do Meio Ambiente, Secretaria de Biodiversidade e Florestas, Departamento de Conservacao da Biodiversidade, Brasilia, Brazil

WBI (2011) Estimating the opportunity costs of REDD+, vol Version 1.3, A training manual. The World Bank Institute, Washington DC

WRI (2011) Mainstreaming Ecosystem Services Initiative (MESI). World Resources Institute, Washington, United States of America, Available via WRI. http:// www.wri.org/project/mainstreaming-ecosystem-services

Wunder S, Alban M (2008) Decentralized payments for environmental services: The cases of Pimampiro and PROFAFOR in Ecuador. Ecol Econ 65(4):685-698

Zimmer Y, Deblitz C, Seifert K (2009) Die globale Landwirtschaft besser verstehen : Agrarokonomen betreiben internationales Netzwerk agri benchmark, Forschung Report. Agribenchmark, Braunschweig, Germany

doi:10.1186/s13717-014-0016-7

Cite this article as: Rodríguez Osuna et al:: Priority areas for watershed service conservation in the Guapi-Macacu region of Rio de Janeiro, Atlantic Forest, Brazil. Ecological Processes 2014 3:16.

\section{Submit your manuscript to a SpringerOpen ${ }^{\circ}$ journal and benefit from:}

- Convenient online submission

- Rigorous peer review

- Immediate publication on acceptance

- Open access: articles freely available online

- High visibility within the field

- Retaining the copyright to your article

Submit your next manuscript at $\gg$ springeropen.com 